\title{
Chemical composition and biological activities of whole and dehulled hemp (Cannabis sativa L.) seeds
}

\author{
José Ignacio Alonso-Esteban $^{\mathrm{a}, \mathrm{b}}$, José Pinela ${ }^{\mathrm{b}}$, Ana Ćirićc ${ }^{\mathrm{c}}$, Ricardo C. Calhelha ${ }^{\mathrm{b}}$, \\ Marina Sokovićc $^{c}$, Isabel C.F.R. Ferreira ${ }^{b}$, Lillian Barros ${ }^{\text {b, }}$, Esperanza Torija-Isasa ${ }^{a}$, \\ María de Cortes Sánchez-Mata ${ }^{\text {a }}$

\footnotetext{
a Department of Nutrition and Food Science, Faculty of Pharmacy, Complutense University of Madrid, Plaza Ramón y Cajal s/n, 28040 Madrid, Spain

${ }^{\mathrm{b}}$ Centro de Investigação de Montanha (CIMO), Instituto Politécnico de Bragança, Campus de Santa Apolónia, 5300-253 Bragança, Portugal

${ }^{\mathrm{c}}$ Institute for Biological Research "Siniša Stanković"- National Institute of Republic of Serbia, University of Belgrade, Bulevar despota Stefana 142, 11000 Belgrade,
} \\ Serbia
}

\section{A R T I C L E I N F O}

\section{Keywords:}

Cannabaceae

Macronutrients

Soluble sugars

Organic acids

Phenolic compounds

Bioactivities

\begin{abstract}
A B S T R A C T
This study aimed to determine a complete chemical composition of eight different varieties of whole hemp seeds and eight samples of commercial dehulled hemp seeds. We also evaluated the phenolic profiles and antioxidant, cytotoxic, and antimicrobial properties of hydromethanolic seed extracts. Whole hemp seeds contain much more fibre than dehulled hemp seeds, which contain more fat and protein. Sucrose and raffinose were the most abundant soluble sugars, and citric and oxalic acids were the most abundant organic acids. In the hydromethanolic hemp seed extracts, we detected the phenolic acids ferulic acid-hexoside and syringic acid. Whole hemp seed extracts exhibited better antioxidant activity than dehulled hemp seed extracts, especially in the TBARS assay. Cytotoxic activity against NCI-H460 cells was also observed. The dehulled hemp seed extracts displayed antibacterial activity, especially against Bacillus cereus, Listeria monocytogenes, and Enterococcus faecalis, and antifungal activity to a lesser extent.
\end{abstract}

\section{Introduction}

Hemp (Cannabis sativa L., Cannabaceae) is a widespread herbaceous plant native to Central Asia. It is thought that hemp was cultivated in China 8500 years ago, making it one of the first crops. The versatility of this plant has driven its cultivation. Indeed, hemp is utilised in industrial, medicinal and food sectors. For example, hemp fibre, obtained from the plant stems (i.e., phloem), is traditionally used in the shipbuilding industry and for other purposes. Moreover, female flowers exhibit pharmacological activity, and seeds are used mainly as food (Small, 2015).

From the nutrition point of view, hemp seeds contain large amounts of nutrients such as fibre (27-36 g/100 g), fat (25-35 g/100 g), and protein (21-28 g/100 g). Concerning fatty acids, hemp seeds contain significant amounts of linoleic acid, which accounts for more than half of total fatty acids. The remaining fatty acid content is comprised of $\alpha$-linolenic acid (16-19\%), oleic acid (12-17\%), palmitic acid (5-8\%), $\gamma$-linolenic acid (1-3\%), and some other minor fatty acids (Callaway,
2004; House, Neufeld, \& Leson, 2010; Vonapartis, Aubin, Seguin, Mustafa, \& Charron, 2015; Alonso-Esteban et al., 2020).

Hemp is known for its psychotropic and medicinal effects and complex phytochemistry. A variety of compounds, including phenolic compounds (mainly flavonoids, stilbenoids, and lignanamides), terpenoids, alkaloids, and cannabinoids, which are the most distinctive compounds, are synthesised by its secondary metabolism (FloresSánchez \& Verpoorte, 2008). Cannabinoids are almost exclusively produced in glandular trichomes, located in the bracts of future female flowers. Other plant parts and seeds also contain cannabinoids; however, the content is significantly lower than in the bracts (Small and Naraine, 2016). The best-known cannabinoid is $\Delta^{9}$-tetrahydrocannabinol $\left(\Delta^{9}\right.$-THC), which has psychoactive activity and medicinal properties. In the European Union, approved cultivated hemp varieties contain a $\Delta^{9}$-THC concentration of $<0.2 \%$ (European Parliament \& Council of the European Union, 2013).

Nowadays, there is an increased consumption of hemp seeds and derivative food products, especially among vegans. While whole hemp

\footnotetext{
* Corresponding author.

E-mail address: lillian@ipb.pt (L. Barros).
} 
seeds can be consumed as food (e.g., roasted seed snacks), they are primarily used as raw material for development of other products such as hemp seed flour, oil, and protein. Hemp protein and hemp flour are by-products obtained from the oil extraction and can be used as an alternative to soy ingredients (Zając et al., 2019). On the other hand, dehulled hemp seeds are commonly marketed as a functional food due to their claimed functional properties (Alonso-Esteban et al., 2020).

The objective of this study was to determine the chemical composition and biological properties of different hemp seed varieties and commercial dehulled hemp seeds. Towards this goal, we analysed the proximate composition, soluble sugars, organic acids, and phenolic compounds and evaluated the antioxidant, cytotoxic, and antimicrobial properties of whole and dehulled hemp seeds.

\section{Material and methods}

\subsection{Plant material}

Eight varieties of whole hemp seeds were supplied by "Cánamo Bajo Aragón" from their crops, located in the province of Teruel, Spain. 'Bialobrzeskie', 'Carmagnola', 'Fedora 17', 'Felina 32', 'KC Dora', 'Kompolti', 'Santhica 27', and 'Tiborszallasi' were the studied varieties, which are included in the Plant Variety Database of the European Commission (2021). Eight commercial samples of dehulled hemp seeds were purchased in different Spanish markets. The variety of these seeds was unknown, as well as their origin. Therefore, two lots of four different widely marketed brands were chosen in order to obtain a broad and representative range of this food product. The samples were cleaned when necessary and stored in a desiccator. Before analysis, all seed samples were reduced to a fine powder $(0.8 \mathrm{~mm})$ with a grinder.

\subsection{Proximate composition and energy value determination}

Moisture was determined by desiccation at $103 \pm 2{ }^{\circ} \mathrm{C}$ to constant weight, according to AOAC 984.25 (Horwitz, 2000). Protein content was determined by the Kjeldahl method, according to AOAC 920.87 (Horwitz, 2000), and total nitrogen content was converted to protein using the nitrogen-protein conversion factor 5.3. Fat content was determined by Soxhlet extraction with petroleum ether as the solvent, according to AOAC 920.39 (Horwitz, 2000). Available carbohydrate content was determined by the anthrone colorimetric method, according to Osborne and Voogt (1986). Before performing the assay, samples are subjected to starch hydrolysis with perchloric acid 52\% (v/v) monitored spectrophotometrically at $630 \mathrm{~nm}$. The fibre content was determined as neutral detergent fibre according to Van Soest and Wine (1967). Total mineral content was determined as ash by incineration at $550 \pm 15^{\circ} \mathrm{C}$, according to AOAC 923.03 (Horwitz, 2000). The results of these determinations were expressed as $\mathrm{g} / 100 \mathrm{~g}$ of fresh weight ( $\mathrm{fw}$ ).

Energy values were calculated using the following conversion factors: $4 \mathrm{kcal} / \mathrm{g}$ for proteins and carbohydrates, $9 \mathrm{kcal} / \mathrm{g}$ for fat, and 2 $\mathrm{kcal} / \mathrm{g}$ for fibre (European Parliament \& Council of the European Union, 2011). The results of these calculations are expressed in $\mathrm{kcal} / 100 \mathrm{~g} \mathrm{fw}$.

Hemp seeds were classified according to Regulation (EC) No 1924/ 2006 on nutrition and health claims made on foods (European Parliament \& Council of the European Union, 2006).

\subsection{Analysis of soluble sugars}

Soluble sugars were analysed according to Pinela et al. (2016). Powdered samples were spiked with the internal standard melezitose $(25 \mathrm{mg} / \mathrm{mL})$ and extracted with ethanol/water $80: 20(\mathrm{v} / \mathrm{v})$ at $80^{\circ} \mathrm{C}$. The analysis was performed in a high-performance liquid chromatography (HPLC) system coupled to a refraction index (RI) detector. Chromatographic separation was achieved with a Eurospher $100-5 \mathrm{NH}_{2}$ column ( $4.6 \times 250 \mathrm{~mm}, 5 \mu \mathrm{m}$, Knauer). The mobile phase was acetonitrile/water $70: 30(\mathrm{v} / \mathrm{v})$. Soluble sugars were identified by chromatographic comparisons with authentic standards and quantified based on the internal standard concentration. The results are expressed in $\mathrm{g} / 100 \mathrm{~g} \mathrm{fw}$.

\subsection{Analysis of organic acids}

Organic acids were determined by ultrafast liquid chromatography (UFLC) coupled to photodiode array detector (PDA) after extraction with meta-phosphoric acid $4.5 \%(\mathrm{w} / \mathrm{v})$, according to a procedure previously described by Pereira, Barros, Carvalho, and Ferreira (2013). Chromatographic separation was achieved on a SphereClone (Phenomenex) reverse phase $\mathrm{C} 18$ column $(250 \times 4.6 \mathrm{~mm}, 5 \mu \mathrm{m})$. Elution was performed with sulphuric acid $3.6 \mathrm{mM}$. Detection was carried out with a PDA, measuring the absorption at 215 and $245 \mathrm{~nm}$ (for ascorbic acid). Organic acids were quantified by comparing the peak areas with calibration curves obtained from commercial standards. The results are expressed in $\mathrm{mg} / 100 \mathrm{~g}$ fw.

\subsection{Analysis of phenolic compounds}

Phenolic compounds were analysed in hemp seed hydromethanolic extracts obtained by solid-liquid extraction as previously described by Pereira, Barros, Carvalho, and Ferreira (2011). Dry extracts ( $10 \mathrm{mg}$ ) were dissolved in $2 \mathrm{~mL}$ of methanol/water 20:80 (v/v) and filtered through $0.22 \mu \mathrm{m}$ disposable filter disks. The analysis was carried out in a Dionex Ultimate 3000 UPLC system (Thermo Scientific, San Jose, CA, USA) equipped with a diode array detector (DAD, 280 and $370 \mathrm{~nm}$ ) coupled to an electrospray ionisation mass spectrometer (ESI-MS) detector. The system and analytical procedures were previously described by Bessada, Barreira, Barros, Ferreira, and Oliveira (2016). MS detection was performed in negative mode, using a Linear Ion Trap LTQ XL mass spectrometer (Thermo Finnigan, San Jose, CA, USA) equipped with an ESI source. Phenolic compounds were identified based on their chromatographic behaviour, UV-Vis and mass spectra by comparing the collected data with standard compounds (when available) and data reported in the literature. A calibration curve based on the UV-Vis signal for each available phenolic standard was constructed for quantitative analysis. The results are expressed in $\mathrm{mg} / \mathrm{g}$ of dry extract.

\subsection{Determination of biological activities}

Antioxidant, cytotoxic, and antimicrobial activities were evaluated in the same extracts used for the phenolic compound analyses. The antioxidant activity of the extracts (at concentrations from 0.156 to 40 $\mathrm{mg} / \mathrm{mL}$ ) was evaluated in vitro using the 2,2-diphenyl-1-picrylhydrazyl (DPPH) free radical scavenging capacity, reducing power, $\beta$-carotene bleaching inhibition, and thiobarbituric acid reactive substances (TBARS) formation inhibition assays, as described previously by Pinela et al. (2012). Results are presented as half maximal effective concentration $\left(\mathrm{EC}_{50}\right)$ values $(\mu \mathrm{g} / \mathrm{mL})$. The sulforhodamine $\mathrm{B}$ assay was performed to evaluate the cytotoxic activity of the hydromethanolic extracts (at concentrations from 0.125 to $4 \mathrm{mg} / \mathrm{mL}$ ) against the MCF-7 (breast adenocarcinoma), NCI-H460 (non-small cell lung cancer), HeLa (cervical carcinoma), and HepG2 (hepatocellular carcinoma) human tumour cell lines, and PLP2 non-tumour primary cells, as previously described by Pires et al. (2018). The authors previously described the procedures and the origin of cell lines. Cytotoxic and hepatotoxic activity results are presented as half-maximal growth inhibition concentration $\left(\mathrm{GI}_{50}\right)$ values $(\mu \mathrm{g} / \mathrm{mL})$. For antimicrobial activity analysis, hydromethanolic extracts (at concentrations from 0.005 to 5 $\mathrm{mg} / \mathrm{mL}$ ) were tested against Bacillus cereus (food isolate), Staphylococcus aureus (ATCC 11632), Listeria monocytogenes (NCTC 7973), and Enterococcus faecalis (ATCC 19433) (Gram-positive bacteria), and Escherichia coli (ATCC 35218) and Salmonella enterica serovar Typhimurium (ATCC 13311) (Gram-negative bacteria) (Soković, Glamočlija, Marin, Brkić, \& van Griensven, 2010). Additionally, antifungal activity was evaluated against Aspergillus fumigatus (ATCC 1022), Aspergillus ochraceus (ATCC 
12066), Aspergillus niger (ATCC 6275), Penicillium ochrochloron (ATCC 9112), Penicillium funiculosum (ATCC 36839), and Penicillium verrucosum var. cyclopium (food isolate) (Soković \& van Griensven, 2006). The authors previously described the procedures and the origin of the microorganisms. As positive controls for the antibacterial activity assay, streptomycin and ampicillin (Sigma-Aldrich) were used. Alternatively, ketoconazole and bifonazole were used as the positive controls for the antifungal assays. The results are presented as minimum inhibitory (MIC) and minimum bactericidal (MBC) or minimum fungicidal (MFC) concentrations $(\mathrm{mg} / \mathrm{mL})$.

\subsection{Statistical analysis}

The experiments were carried out in triplicate, and the results were expressed as mean \pm standard deviation (SD). One-way analysis of variance (ANOVA), using the SPSS Statistics software (IBM SPSS Statistics for Mac, Version 21.0. Armonk, NY, IBM Corp.), was applied to detect statistically significant differences ( $p$-value $<0.05$ ) between whole and dehulled hemp seed samples. The homogeneity of variance was assessed using Levene's test. All dependent variables were compared using Tukey's honestly significant difference (HSD) or Tamhane's T2 multiple comparison tests, when homoscedasticity was verified or not, respectively.

\section{Results and discussion}

\subsection{Proximate composition}

Proximate composition results of whole and dehulled hemp seeds are summarised in Tables 1 and 2, respectively. The moisture in hemp seeds was low, ranging from 4.53 to $7.06 \mathrm{~g} / 100 \mathrm{~g}$ in whole and 4.50 to $6.56 \mathrm{~g} /$ $100 \mathrm{~g}$ in dehulled seeds. In general, the whole hemp seeds results are consistent with previous studies (Callaway, 2004; House, Neufeld, \& Leson, 2010; Vonapartis, Aubin, Seguin, Mustafa, \& Charron, 2015). Vonapartis et al. (2015) reported a lower moisture content value of 1.13 $\mathrm{g} / 100 \mathrm{~g}$ in the 'Alyssa' variety, which was not evaluated in this study. Another study by Zając et al. (2019) reported a moisture content of 6.8 $\mathrm{g} / 100 \mathrm{~g}$ for the 'Bialobrzeskie' variety, which is slightly higher than our result of $4.53 \mathrm{~g} / 100 \mathrm{~g}$. Environmental features could explain these differences, but storage conditions too, particularly temperature. The moisture of dehulled hemp seeds seems consistent with previous works (Callaway \& Pate, 2009; House et al., 2010; USDA, 2019; Zając et al., 2019), but there are slight differences in other nutrients.

The neutral detergent fibre was the most abundant fraction of the whole hemp seeds. The fibre content was greater than $30 \mathrm{~g} / 100 \mathrm{~g}$ in all eight varieties analysed, with values higher than $40 \mathrm{~g} / 100 \mathrm{~g}$ in the 'Kompolti' and 'Tiborszallasi' varieties. The fibre content is difficult to compare with literature because the analytical method influences the fibre fractions determined. For example, Callaway (2004) reported a fibre content of $27.6 \mathrm{~g} / 100 \mathrm{~g}$ in 'Finola'. While this value is out of the fibre content range reported herein, the employed methodology is unknown, and we did not analyse this variety. Vonapartis et al. (2015) determined neutral detergent fibre, as we did, and their results are similar to those here presented. In their study, all the analysed varieties contained more than $30 \mathrm{~g} / 100 \mathrm{~g}$, but none were greater than $40 \mathrm{~g} / 100 \mathrm{~g}$. It should be pointed out that Vonapartis et al. (2015) analysed the 'Finola' variety and reported a value that was over $30 \mathrm{~g} / 100 \mathrm{~g}$, which is greater than previously reported by Callaway (2004). Vonapartis et al. (2015) also reported acid detergent fibre values lower than those for neutral detergent fibre. House et al. (2010) presented results consistent with Vonapartis et al. (2015) and herein. Besides, Vonapartis et al. (2015) reported that cellulose, hemicellulose, and lignin (i.e., components of insoluble fibre) contents were around 15, 7.5 and $10.5 \mathrm{~g} / 100 \mathrm{~g}$, respectively, which would make the insoluble fibre content greater than $30 \mathrm{~g} / 100 \mathrm{~g}$. Lastly, Zając et al. (2019) reported a total fibre content of $42.83 \mathrm{~g} / 100 \mathrm{~g}$, a result greater than our maximum result. House et al. (2010) determined neutral detergent fibre, and their average value was $7.8 \mathrm{~g} / 100 \mathrm{~g}$. However, this value was overestimated because one sample had a high neutral detergent fibre content, $18.1 \mathrm{~g} / 100 \mathrm{~g}$, but the rest of the samples displayed lower values, some of which were within our range. USDA (2019) reported a fibre content of $4.0 \mathrm{~g} / 100 \mathrm{~g}$, close to the average value of the present study, $4.57 \mathrm{~g} / 100 \mathrm{~g}$. According to European regulations (European Parliament \& Council of the European Union, 2006), food can use the nutrition claim "source of fibre" if it contains at least $3 \mathrm{~g} / 100 \mathrm{~g}$ and can claim "high fibre" if it contains $6 \mathrm{~g} / 100 \mathrm{~g}$ or more. In this sense, whole hemp seeds could be labelled as "high fibre content", and dehulled seeds as "source of fibre".

Fat content ranged from 29.1 to $32.66 \mathrm{~g} / 100 \mathrm{~g}$ in whole hemp seeds,

Table 1

Proximate composition, energy value and its distribution by nutrient, soluble sugars and organic acids of whole hemp seeds. The results are presented as the mean \pm standard deviation $(\mathrm{n}=3)$.

\begin{tabular}{|c|c|c|c|c|c|c|c|c|}
\hline & 'Bialobrzeskie' & 'Carmagnola' & 'Fedora 17' & 'Felina 32' & 'KC Dora' & 'Kompolti' & 'Santhica 27' & 'Tiborszallasi' \\
\hline \multicolumn{9}{|c|}{ Proximate composition $(\mathrm{g} / 100 \mathrm{~g})$} \\
\hline Moisture & $4.53 \pm 0.06^{\mathrm{f}}$ & $5.2 \pm 0.2^{\mathrm{a}, \mathrm{b}, \mathrm{c}, \mathrm{d}, \mathrm{e}, \mathrm{f}}$ & $5.67 \pm 0.03^{\mathrm{e}}$ & $6.72 \pm 0.02^{\mathrm{b}}$ & $6.04 \pm 0.04^{c}$ & $7.06 \pm 0.01^{\mathrm{a}}$ & $5.94 \pm 0.04^{\mathrm{c}, \mathrm{d}}$ & $5.73 \pm 0.05^{\mathrm{d}, \mathrm{e}}$ \\
\hline Protein & $23.0 \pm 0.5^{\mathrm{a}}$ & $21.9 \pm 0.3^{\mathrm{a}, \mathrm{b}}$ & $19.8 \pm 0.8^{\mathrm{c}, \mathrm{d}}$ & $18.3 \pm 0.8^{\mathrm{d}}$ & $21.2 \pm 0.5^{\mathrm{b}, \mathrm{c}}$ & $18.8 \pm 0.2^{\mathrm{d}}$ & $18.3 \pm 0.9^{\mathrm{d}}$ & $22.3 \pm 0.6^{\mathrm{a}, \mathrm{b}}$ \\
\hline Fat & $32.66 \pm 0.01^{\mathrm{a}}$ & $32.3 \pm 0.2^{\mathrm{a}}$ & $31.3 \pm 0.3^{\mathrm{a}, \mathrm{b}, \mathrm{c}}$ & $29.8 \pm 0.9^{\mathrm{c}, \mathrm{d}}$ & $31.5 \pm 0.2^{\mathrm{a}, \mathrm{b}}$ & $31.7 \pm 0.2^{\mathrm{a}}$ & $29.9 \pm 0.9^{\mathrm{b}, \mathrm{c}, \mathrm{d}}$ & $29.1 \pm 0.8^{\mathrm{d}}$ \\
\hline $\mathrm{ACH}$ & $10.28 \pm 0.04^{\mathrm{a}}$ & $9.1 \pm 0.5^{b}$ & $9.3 \pm 0.2^{\mathrm{a}, \mathrm{b}}$ & $9.4 \pm 0.5^{\mathrm{a}, \mathrm{b}}$ & $8.7 \pm 0.5^{b}$ & $9.4 \pm 0.4^{\mathrm{a}, \mathrm{b}}$ & $10.4 \pm 0.3^{\mathrm{a}}$ & $9.6 \pm 0.5^{\mathrm{a}, \mathrm{b}}$ \\
\hline $\mathrm{NDF}$ & $32.5 \pm 0.5^{\mathrm{d}}$ & $39.5 \pm 0.2^{\mathrm{a}, \mathrm{b}, \mathrm{c}}$ & $36.6 \pm 0.3^{c}$ & $38 \pm 2^{\mathrm{a}, \mathrm{b}, \mathrm{c}}$ & $37 \pm 2^{\mathrm{b}, \mathrm{c}}$ & $40.4 \pm 0.8^{\mathrm{a}}$ & $37.44 \pm 0.02^{\mathrm{a}, \mathrm{b}, \mathrm{c}}$ & $40.0 \pm 1.2^{\mathrm{a}, \mathrm{b}}$ \\
\hline TMC & $4.56 \pm 0.08^{\mathrm{f}}$ & $5.46 \pm 0.02^{\mathrm{b}, \mathrm{c}}$ & $4.84 \pm 0.01^{\mathrm{e}}$ & $5.1 \pm 0.1^{\mathrm{d}}$ & $5.29 \pm 0.07^{c, d}$ & $6.32 \pm 0.09^{\mathrm{a}}$ & $4.2 \pm 0.1^{g}$ & $5.69 \pm 0.08^{\mathrm{b}}$ \\
\hline \multicolumn{9}{|c|}{ Energy value (kcal/100 g) and its distribution by nutrient (\%) } \\
\hline Energy value & $492 \pm 2^{\mathrm{a}}$ & $494 \pm 5^{\mathrm{a}, \mathrm{b}}$ & $471 \pm 4^{\mathrm{a}, \mathrm{b}}$ & $456 \pm 10^{\mathrm{a}, \mathrm{b}}$ & $476 \pm 3^{\mathrm{a}, \mathrm{b}}$ & $479 \pm 2^{\mathrm{b}}$ & $459 \pm 9^{\mathrm{a}, \mathrm{b}}$ & $469 \pm 8^{\mathrm{a}, \mathrm{b}}$ \\
\hline Protein & $18.7 \pm 0.3^{\mathrm{a}}$ & $21.9 \pm 0.3^{\mathrm{a}, \mathrm{b}}$ & $16.8 \pm 0.6^{\mathrm{b}, \mathrm{c}}$ & $16 \pm 1^{\mathrm{c}}$ & $17.8 \pm 0.4^{\mathrm{a}, \mathrm{b}}$ & $15.7 \pm 0.2^{\mathrm{c}}$ & $16.0 \pm 0.6^{\mathrm{c}}$ & $19.0 \pm 0.4^{\mathrm{a}}$ \\
\hline Fat & $59.8 \pm 0.2^{\mathrm{a}}$ & $58.8 \pm 0.3^{\mathrm{a}}$ & $59.8 \pm 0.6^{\mathrm{a}}$ & $58.9 \pm 0.6^{\mathrm{a}}$ & $59.4 \pm 0.6^{\mathrm{a}}$ & $59.6 \pm 0.3^{\mathrm{a}}$ & $58.7 \pm 0.8^{\mathrm{a}}$ & $55.8 \pm 0.6^{\mathrm{b}}$ \\
\hline $\mathrm{ACH}$ & $8.36 \pm 0.04^{\mathrm{a}, \mathrm{b}}$ & $7.4 \pm 0.4^{\mathrm{c}, \mathrm{d}}$ & $7.9 \pm 0.1^{\mathrm{b}, \mathrm{c}, \mathrm{d}}$ & $8.3 \pm 0.4^{\mathrm{a}, \mathrm{b}, \mathrm{c}}$ & $7.3 \pm 0.4^{\mathrm{d}}$ & $7.9 \pm 0.4^{b, c, d}$ & $9.0 \pm 0.4^{\mathrm{a}}$ & $8.2 \pm 0.3^{\mathrm{a}, \mathrm{b}, \mathrm{c}, \mathrm{d}}$ \\
\hline NDF & $13.2 \pm 0.2^{\mathrm{d}}$ & $16.0 \pm 0.1^{\mathrm{a}, \mathrm{b}, \mathrm{c}}$ & $15.6 \pm 0.2^{\mathrm{b}, \mathrm{c}}$ & $16.8 \pm 0.5^{\mathrm{a}, \mathrm{b}, \mathrm{c}}$ & $15.5 \pm 0.9^{c}$ & $16.9 \pm 0.3^{\mathrm{a}, \mathrm{b}}$ & $16.3 \pm 0.3^{\mathrm{a}, \mathrm{b}, \mathrm{c}}$ & $17.1 \pm 0.7^{\mathrm{a}}$ \\
\hline \multicolumn{9}{|c|}{ Soluble sugars $(\mathrm{g} / 100 \mathrm{~g})$} \\
\hline Fructose & $0.60 \pm 0.01^{\mathrm{a}}$ & $0.113 \pm 0.002^{\mathrm{b}}$ & nd & $0.113 \pm 0.003^{\mathrm{b}}$ & nd & nd & nd & nd \\
\hline Glucose & $0.78 \pm 0.01^{\mathrm{a}}$ & $0.232 \pm 0.006^{\mathrm{b}}$ & nd & $0.121 \pm 0.003^{c}$ & nd & nd & nd & nd \\
\hline Sucrose & $1.69 \pm 0.03^{h}$ & $2.99 \pm 0.03^{\mathrm{d}}$ & $3.62 \pm 0.04^{\mathrm{b}}$ & $2.62 \pm 0.03^{\mathrm{e}}$ & $2.32 \pm 0.06^{g}$ & $2.47 \pm 0.02^{\mathrm{f}}$ & $3.87 \pm 0.05^{\mathrm{a}}$ & $3.16 \pm 0.01^{\mathrm{c}}$ \\
\hline Raffinose & $0.65 \pm 0.01^{\mathrm{d}}$ & $0.548 \pm 0.009^{\mathrm{e}}$ & $0.99 \pm 0.04^{\mathrm{a}}$ & $0.97 \pm 0.03^{\mathrm{a}}$ & $0.82 \pm 0.02^{\mathrm{b}}$ & $0.81 \pm 0.02^{\mathrm{b}, \mathrm{c}}$ & $0.752 \pm 0.004^{c}$ & $0.49 \pm 0.02^{\mathrm{f}}$ \\
\hline Total & $3.73 \pm 0.07^{\mathrm{c}, \mathrm{d}}$ & $3.88 \pm 0.01^{\mathrm{b}}$ & $4.61 \pm 0.01^{\mathrm{a}}$ & $3.82 \pm 0.05^{\mathrm{b}, \mathrm{c}}$ & $3.14 \pm 0.08^{\mathrm{f}}$ & $3.28 \pm 0.05^{\mathrm{e}}$ & $4.62 \pm 0.05^{\mathrm{a}}$ & $3.64 \pm 0.03^{d}$ \\
\hline \multicolumn{9}{|c|}{ Organic acids (mg/100 g) } \\
\hline Oxalic acid & $128 \pm 5^{c}$ & $94 \pm 2^{d}$ & $87.1 \pm 0.8^{\mathrm{d}}$ & $51 \pm 4^{\mathrm{f}}$ & $64 \pm 1^{\mathrm{e}}$ & $18.5 \pm 0.3^{g}$ & $155.0 \pm 0.2^{\mathrm{b}}$ & $191 \pm 2^{\mathrm{a}}$ \\
\hline Citric acid & $213 \pm 2^{\mathrm{b}}$ & $85 \pm 3^{e}$ & $186 \pm 4^{c}$ & $119 \pm 7^{\mathrm{d}}$ & $218 \pm 10^{\mathrm{b}}$ & $128 \pm 6^{\mathrm{d}}$ & $353 \pm 4^{\mathrm{a}}$ & $186 \pm 8^{c}$ \\
\hline Fumaric acid & $\operatorname{tr}$ & $\operatorname{tr}$ & $\operatorname{tr}$ & $\operatorname{tr}$ & $\operatorname{tr}$ & $\operatorname{tr}$ & $\operatorname{tr}$ & $\operatorname{tr}$ \\
\hline
\end{tabular}

ACH: available carbohydrates; NDF: neutral detergent fibre; TMC: total mineral content; nd: not detected; tr: traces. Different letters in the same line indicate significant differences $(p<0.001)$ between samples. 
Table 2


standard deviation $(n=3)$.

\begin{tabular}{|c|c|c|c|c|c|c|c|c|}
\hline & Brand 1 lot 1 & Brand 1 lot 2 & Brand 2 lot 1 & Brand 2 lot 2 & Brand 3 lot 1 & Brand 3 lot 2 & Brand 4 lot 1 & Brand 4 lot 2 \\
\hline \multicolumn{9}{|c|}{ Proximate composition $(\mathrm{g} / \mathbf{1 0 0} \mathrm{g})$} \\
\hline Moisture & $5.6 \pm 0.3^{\mathrm{a}, \mathrm{b}, \mathrm{c}, \mathrm{d}, \mathrm{e}}$ & $6.25 \pm 0.03^{b}$ & $6.56 \pm 0.02^{\mathrm{a}}$ & $4.96 \pm 0.04^{\mathrm{d}}$ & $6.07 \pm 0.02^{\mathrm{c}}$ & $4.50 \pm 0.02^{\mathrm{e}}$ & $5.48 \pm 0.09^{\mathrm{b}, \mathrm{c}, \mathrm{d}, \mathrm{e}}$ & $4.60 \pm 0.02^{\mathrm{e}}$ \\
\hline Protein & $28.4 \pm 0.3^{\mathrm{a}}$ & $28.3 \pm 0.2^{\mathrm{a}}$ & $24.6 \pm 0.2^{\mathrm{c}}$ & $24.85 \pm 0.09^{c}$ & $25.4 \pm 0.1^{\mathrm{b}, \mathrm{c}}$ & $25.3 \pm 0.2^{\mathrm{b}, \mathrm{c}}$ & $25.6 \pm 0.5^{\mathrm{b}}$ & $25.0 \pm 0.2^{\mathrm{b}, \mathrm{c}}$ \\
\hline Fat & $49.6 \pm 0.4^{\mathrm{e}}$ & $50.2 \pm 0.3^{\mathrm{e}}$ & $52.6 \pm 0.3^{c}$ & $51.58 \pm 0.04^{\mathrm{d}}$ & $52.1 \pm 0.4^{\mathrm{c}, \mathrm{d}}$ & $51.7 \pm 0.2^{\mathrm{c}, \mathrm{d}}$ & $55.0 \pm 0.5^{\mathrm{a}}$ & $53.77 \pm 0.02^{\mathrm{b}}$ \\
\hline $\mathrm{ACH}$ & $4.7 \pm 0.2^{\mathrm{c}, \mathrm{d}}$ & $4.5 \pm 0.3^{\mathrm{d}, \mathrm{e}}$ & $5.46 \pm 0.09^{\mathrm{a}, \mathrm{b}}$ & $5.2 \pm 0.2^{\mathrm{b}, \mathrm{c}}$ & $5.2 \pm 0.1^{\mathrm{b}, \mathrm{c}}$ & $5.9 \pm 0.1^{\mathrm{a}}$ & $4.0 \pm 0.2^{\mathrm{e}}$ & $5.31 \pm 0.08^{\mathrm{b}}$ \\
\hline NDF & $4.8 \pm 0.2^{c}$ & $6.0 \pm 0.2^{\mathrm{a}}$ & $5.1 \pm 0.3^{\mathrm{b}, \mathrm{c}}$ & $5.9 \pm 0.4^{\mathrm{a}, \mathrm{b}}$ & $4.4 \pm 0.4^{\mathrm{c}, \mathrm{d}}$ & $3.9 \pm 0.2^{\mathrm{d}}$ & $3.6 \pm 0.3^{\mathrm{d}, \mathrm{e}}$ & $2.92 \pm 0.06^{\mathrm{e}}$ \\
\hline TMC & $5.79 \pm 0.03^{\mathrm{a}, \mathrm{b}}$ & $5.96 \pm 0.06^{\mathrm{a}}$ & $4.94 \pm 0.05^{\mathrm{d}}$ & $5.1 \pm 0.1^{\mathrm{b}, \mathrm{d}}$ & $5.45 \pm 0.08^{\mathrm{b}, \mathrm{c}}$ & $5.08 \pm 0.03^{\mathrm{c}, \mathrm{d}}$ & $4.99 \pm 0.02^{\mathrm{c}, \mathrm{d}}$ & $5.3 \pm 0.2^{\mathrm{a}, \mathrm{c}, \mathrm{d}}$ \\
\hline \multicolumn{9}{|c|}{ Energy value (kcal/100 g) and its distribution by nutrient (\%) } \\
\hline Energy value & $589 \pm 4^{\mathrm{e}}$ & $595 \pm 3^{\mathrm{d}, \mathrm{e}}$ & $604 \pm 3^{\mathrm{b}, \mathrm{c}}$ & $596.2 \pm 0.4^{\mathrm{c}, \mathrm{d}, \mathrm{e}}$ & $600 \pm 4^{\mathrm{c}, \mathrm{d}}$ & $598 \pm 2^{\mathrm{c}, \mathrm{d}}$ & $621 \pm 5^{\mathrm{a}}$ & $611.1 \pm 0.9^{b}$ \\
\hline Protein & $19.3 \pm 0.2^{\mathrm{a}}$ & $19.04 \pm 0.02^{\mathrm{a}}$ & $16.3 \pm 0.2^{\mathrm{b}}$ & $16.67 \pm 0.05^{\mathrm{b}}$ & $16.9 \pm 0.1^{\mathrm{b}}$ & $16.9 \pm 0.1^{\mathrm{b}}$ & $16.5 \pm 0.3^{\mathrm{b}}$ & $16.4 \pm 0.1^{\mathrm{b}}$ \\
\hline Fat & $75.9 \pm 0.1^{\mathrm{c}}$ & $76.0 \pm 0.2^{\mathrm{c}}$ & $78.39 \pm 0.02^{\mathrm{a}, \mathrm{b}}$ & $77.86 \pm 0.08^{\mathrm{b}}$ & $78.1 \pm 0.2^{\mathrm{a}, \mathrm{b}}$ & $77.9 \pm 0.1^{\mathrm{b}}$ & $79.7 \pm 0.4^{\mathrm{a}, \mathrm{b}, \mathrm{c}}$ & $79.2 \pm 0.1^{\mathrm{a}}$ \\
\hline $\mathrm{ACH}$ & $3.2 \pm 0.2^{\mathrm{c}, \mathrm{d}}$ & $3.0 \pm 0.2^{\mathrm{d}}$ & $3.62 \pm 0.06^{\mathrm{a}, \mathrm{b}}$ & $3.5 \pm 0.2^{\mathrm{b}, \mathrm{c}}$ & $3.49 \pm 0.08^{\mathrm{b}, \mathrm{c}}$ & $3.92 \pm 0.09^{\mathrm{a}}$ & $2.6 \pm 0.1^{\mathrm{e}}$ & $3.47 \pm 0.05^{\mathrm{b}, \mathrm{c}}$ \\
\hline $\mathrm{NDF}$ & $1.62 \pm 0.06^{\mathrm{b}}$ & $2.01 \pm 0.06^{\mathrm{a}}$ & $1.69 \pm 0.09^{\mathrm{b}}$ & $2.0 \pm 0.2^{\mathrm{a}}$ & $1.5 \pm 0.1^{\mathrm{b}, \mathrm{c}}$ & $1.29 \pm 0.07^{\mathrm{c}, \mathrm{d}}$ & $1.2 \pm 0.1^{\mathrm{d}, \mathrm{e}}$ & $0.95 \pm 0.02^{\mathrm{e}}$ \\
\hline \multicolumn{9}{|c|}{ Soluble sugars $(\mathrm{g} / 100 \mathrm{~g})$} \\
\hline Fructose & nd & nd & nd & nd & nd & nd & nd & nd \\
\hline Glucose & nd & nd & $1.01 \pm 0.02^{\mathrm{a}}$ & $0.209 \pm 0.004^{\mathrm{e}}$ & $0.851 \pm 0.005^{\mathrm{b}}$ & $0.64 \pm 0.01^{\mathrm{c}}$ & $0.249 \pm 0.002^{\mathrm{d}}$ & $0.241 \pm 0.003^{\mathrm{d}}$ \\
\hline Sucrose & $2.75 \pm 0.01^{\mathrm{e}}$ & $2.74 \pm 0.03^{\mathrm{e}}$ & $3.34 \pm 0.07^{\mathrm{b}}$ & $4.58 \pm 0.04^{\mathrm{a}}$ & $3.00 \pm 0.05^{\mathrm{d}}$ & $4.54 \pm 0.04^{\mathrm{a}}$ & $3.07 \pm 0.03^{\mathrm{c}, \mathrm{d}}$ & $3.14 \pm 0.05^{\mathrm{c}}$ \\
\hline Raffinose & $2.46 \pm 0.07^{\mathrm{a}}$ & $2.26 \pm 0.01^{\mathrm{a}}$ & $0.321 \pm 0.006^{\mathrm{d}, \mathrm{e}}$ & $0.485 \pm 0.007^{\mathrm{b}}$ & $0.257 \pm 0.001^{\mathrm{e}}$ & $0.468 \pm 0.006^{\mathrm{b}}$ & $0.433 \pm 0.005^{c}$ & $0.305 \pm 0.004^{\mathrm{d}}$ \\
\hline Total & $5.21 \pm 0.08^{\mathrm{b} \mathrm{d}}$ & $5.00 \pm 0.02^{\mathrm{c}}$ & $4.7 \pm 0.1^{\mathrm{d}}$ & $5.28 \pm 0.05^{\mathrm{b}}$ & $4.11 \pm 0.06^{\mathrm{e}}$ & $5.65 \pm 0.06^{\mathrm{a}}$ & $3.75 \pm 0.04^{\mathrm{f}}$ & $3.68 \pm 0.05^{\mathrm{f}}$ \\
\hline \multicolumn{9}{|c|}{ Organic acids (mg/100 g) } \\
\hline Oxalic acid & $89 \pm 3^{\mathrm{d}, \mathrm{e}}$ & $81.7 \pm 0.7^{\mathrm{e}}$ & $134 \pm 7^{\mathrm{a}}$ & $91.6 \pm 0.3^{\mathrm{d}}$ & $101 \pm 3^{c}$ & $90.9 \pm 0.2^{\mathrm{d}}$ & $113.8 \pm 0.3^{\mathrm{b}}$ & $116 \pm 2^{\mathrm{b}}$ \\
\hline Citric acid & $260 \pm 2^{c}$ & $223 \pm 9^{\mathrm{d}, \mathrm{e}}$ & $303 \pm 4^{\mathrm{b}}$ & $218 \pm 2^{\mathrm{d}, \mathrm{e}}$ & $207 \pm 6^{\mathrm{e}, \mathrm{f}}$ & $330 \pm 10^{\mathrm{a}}$ & $192 \pm 7^{\mathrm{f}}$ & $225 \pm 3^{\mathrm{d}}$ \\
\hline Fumaric acid & $\operatorname{tr}$ & $\operatorname{tr}$ & $1.5 \pm 0.1^{\mathrm{c}}$ & $2.65 \pm 0.03^{b}$ & $0.678 \pm 0.007^{\mathrm{d}}$ & $\operatorname{tr}$ & $0.60 \pm 0.01^{\mathrm{d}}$ & $3.489 \pm 0.02^{\mathrm{a}}$ \\
\hline
\end{tabular}

ACH: available carbohydrates; NDF: neutral detergent fibre; TMC: total mineral content; nd: not detected; tr: traces. Different letters in the same line indicate significant differences $(p<0.001)$ between samples.

which correspond to the 'Bialobrzeskie' and 'Tiborszallasi' varieties. The fat content was higher in dehulled seeds, with close to or even higher than $50 \mathrm{~g} / 100 \mathrm{~g}$. Vonapartis et al. (2015) reported fat contents slightly lower than ours in whole hemp seeds, while Callaway (2004) published higher results than present values. The data of House et al. (2010) approach the results of the present study, as their average value was $30.4 \mathrm{~g} / 100 \mathrm{~g}$ and the average value in this work was $31.02 \mathrm{~g} / 100 \mathrm{~g}$. The values in this study also seem consistent with Aluko (2017), who indicated a fat content of $30 \mathrm{~g} / 100 \mathrm{~g}$. Zając et al. (2019) reported a fat content for 'Bialobrzeskie' of $30.69 \mathrm{~g} / 100 \mathrm{~g}$, lower than the $32.66 \mathrm{~g} / 100$ $\mathrm{g}$ herein quantified, but still within the range of values. For dehulled hemp seeds, Zając et al. (2019) reported $51.17 \mathrm{~g} / 100 \mathrm{~g}$ of fat, while those of the present study yielded an average value of $52.07 \mathrm{~g} / 100 \mathrm{~g}$.

Protein content was also higher in dehulled hemp seeds compared to whole seeds. On average, the protein content in dehulled seeds was 26 $\mathrm{g} / 100 \mathrm{~g}$, while it was $20.4 \mathrm{~g} / 100 \mathrm{~g}$ in the whole ones. 'Bialobrzeskie' was the variety with the highest protein content, $23.0 \mathrm{~g} / 100 \mathrm{~g}$. While fibre content is difficult to compare because of the methodology, problems comparing protein content come from the nitrogen-protein conversion factor (sometimes different or unknown). The protein content reported by Callaway (2004) is $24.8 \mathrm{~g} / 100 \mathrm{~g}$ in the 'Finola' variety, and the conversion factor is not specified. Vonapartis et al. (2015) used the conversion factor 6.25, yielding a result that was higher than that of Callaway (2004) for the same variety. The same happens with the results of House et al. (2010), causing many of the values to higher than those in the present work, because they also used the conversion factor of 6.25. The data of Aluko (2017) and Zajacc et al. (2019) are also slightly higher than ours. It is plausible that these studies also used the conversion factor of 6.25 too. As with whole hemp seeds, the protein content of dehulled seeds is lower than previously reported by other authors (Callaway \& Pate, 2009; House et al., 2010; Zając et al., 2019). USDA (2019) protein content, $31.56 \mathrm{~g} / 100 \mathrm{~g}$, was calculated with the same conversion factor used in this study (5.3), leading to values entering the range presented here $(24.6-28.4 \mathrm{~g} / 100 \mathrm{~g})$. Nutrition claims about proteins are related to their percentage related to energy value. The claim "source of protein" requires at least $12 \%$ of the energy value provided by protein, and $20 \%$ for "high protein content". Therefore, both whole and dehulled hemp seeds, could use the nutrition claim "source of protein" (European Parliament \& Council of the European Union, 2006).
Whole hemp seeds contained about $9.5 \mathrm{~g} / 100 \mathrm{~g}$ of available carbohydrates, and dehulled seeds contained $5.03 \mathrm{~g} / 100 \mathrm{~g}$ on average. There is not available carbohydrates data in whole hemp seeds from previous studies, while concerning dehulled seeds, very few data are published about available carbohydrates, being estimated by difference, so this is the first study reporting analytical data about available carbohydrates in hemp seeds.

Total mineral content was similar in both sample types, ranging from 4.2 to $6.32 \mathrm{~g} / 100 \mathrm{~g}$ in whole hemp seeds and 4.94 to $5.96 \mathrm{~g} / 100 \mathrm{~g}$ in dehulled seeds. Total mineral content seems to be consistent with previous works (Callaway, 2004; House et al., 2010; Vonapartis et al., 2015). Zając et al. (2019) reported a much higher result for the 'Bialobrzeskie' variety, $10.0 \mathrm{~g} / 100 \mathrm{~g}$, more than twice the result described here for the same variety, $4.56 \mathrm{~g} / 100 \mathrm{~g}$, and more than all ranges reported by the other authors. Total mineral content previously reported was slightly higher than $6 \mathrm{~g} / 100 \mathrm{~g}$, close to our maximum value, $5.96 \mathrm{~g} /$ $100 \mathrm{~g}$. Zając et al. (2019) reported a total mineral content of $17.5 \mathrm{~g} / 100$ $\mathrm{g}$, much higher than the values of this work and other authors.

\subsection{Energy value}

Energy value results and its distribution by nutrient of whole and dehulled hemp seeds are summarised in Tables 1 and 2, respectively. The energy value of whole hemp seeds ranged from 456 to $494 \mathrm{kcal} / 100$ $\mathrm{g}$, and more than half ( $58.8 \%$ on average) corresponded to fat, which is the most energetic nutrient. The energy value of dehulled seeds ranged from 589 to $621 \mathrm{kcal} / 100 \mathrm{~g}$. This augmented energy value is due to their increased fat content, which in some cases accounted for 75 to $79 \%$ of the total energy. Additionally, the protein contribution to the energy value is remarkable, close to $17.2 \%$ in both cases. This result justifies the need to use an appropriate nitrogen-protein conversion factor for seeds to avoid less accurate estimates.

Callaway (2004) reported an energy value of $506 \mathrm{kcal} / 100 \mathrm{~g}$ for whole hemp seeds. This value is slightly higher than that here reported because of the higher fat content of the 'Finola' variety used in that study. House et al. (2010) also reported a higher hemp seed energy value, but the authors used calorimetry and did not include conversion factors in their calculations. USDA (2019) reports $533 \mathrm{kcal} / 100 \mathrm{~g}$ for dehulled hemp seeds. This reduced value compared to ours is because 
that study used lower conversion factors for fat and protein, the most abundant nutrients in this type of seeds. All these results can be very useful in completing food composition databases and for labelling purposes.

\subsection{Soluble sugars}

The results of soluble sugars content of whole and dehulled hemp seeds are presented in Table 1 , and Table 2. Sucrose was the most abundant soluble sugar in whole hemp seeds. Its content ranged from $1.69 \mathrm{~g} / 100 \mathrm{~g}$ in the 'Bialobrzeskie' variety to $3.87 \mathrm{~g} / 100 \mathrm{~g}$ in 'Santhica 27 '. We also detected raffinose at concentrations lower than $1 \mathrm{~g} / 100 \mathrm{~g}$ in all varieties analysed. Fructose and glucose were also detected in the 'Bialobrzeskie', 'Carmagnola', and 'Felina 32 ' varieties. The 'Bialobrzeskie' variety had the highest concentrations of these two monosaccharides, with $0.60 \mathrm{~g} / 100 \mathrm{~g}$ of fructose and $0.78 \mathrm{~g} / 100 \mathrm{~g}$ of glucose. The total soluble sugar content of whole hemp seeds ranged from 3.14 to $4.62 \mathrm{~g} / 100 \mathrm{~g}$. Despite the lack of fructose and glucose, the 'Fedora 17' and 'Santhica 27 ' varieties had the highest total soluble sugar content values because of their high sucrose content.

Total soluble sugars in dehulled hemp seeds ranged from 3.68 and $5.65 \mathrm{~g} / 100 \mathrm{~g}$. They contained sucrose and raffinose and most of them also contained glucose up to $1 \mathrm{~g} / 100 \mathrm{~g}$, but fructose was not detected in any of the samples. Sucrose was the most abundant, with values ranging from 2.74 to $4.58 \mathrm{~g} / 100 \mathrm{~g}$. The raffinose content was lower than $0.5 \mathrm{~g} /$ $100 \mathrm{~g}$ in most samples, but two of them (Brand 1) exceeded $2 \mathrm{~g} / 100 \mathrm{~g}$. Glucose was not detected in the high raffinose-containing samples.

Information about soluble sugars in hemp seeds is scarce. Recently, Schultz et al. (2020) reported the soluble sugars content of dehulled hemp seeds. As in the present work, sucrose and raffinose were the predominant sugars in dehulled seeds, and fructose and glucose were not present in all the analysed samples. Moreover, the observed sucrose content in their samples ranged from 1.5 to $3.8 \mathrm{~g} / 100 \mathrm{~g}$, which is slightly higher than the results here presented. Furthermore, they detected raffinose concentrations of $<0.5 \mathrm{~g} / 100 \mathrm{~g}$, an observation, except the two samples with elevated raffinose levels, consistent with the data presented herein.

\subsection{Organic acids}

The organic acid results from whole and dehulled hemp seeds are shown in Tables 1 and 2, respectively. Citric acid was the most abundant organic acid in most samples of whole hemp seeds analysed with values ranging from 85 to $353 \mathrm{mg} / 100 \mathrm{~g}$. The minimum content corresponded to the 'Carmagnola' variety, one of the two varieties with a citric acid content lower than oxalic acid, which had a content of $94 \mathrm{mg} / 100 \mathrm{~g}$. The other variety was 'Tiborszallasi', which had a citric acid content of 186 $\mathrm{mg} / 100 \mathrm{~g}$ and an oxalic acid content of $191 \mathrm{mg} / 100 \mathrm{~g}$. Thus, the content of these two organic acids was quite similar in these two varieties. The maximum citric acid content corresponded to 'Santhica 27 ', which was the only variety with more than $300 \mathrm{mg} / 100 \mathrm{~g}$. In whole hemp seeds, oxalic acid concentrations ranged from 18.5 to $191 \mathrm{mg} / 100 \mathrm{~g}$. The maximum value was detected in the 'Tiborszallasi' variety, and the 'Kompolti' variety had the lowest levels, roughly one-tenth the maximum. It is important to point out that the differences in oxalic acid content were notable, with statistically significant differences detected between nearly all the samples. The only exception was when we compared the 'Carmagnola' and 'KC Dora' varieties. Only trace amounts of fumaric acid were detected in whole hemp seeds.

In dehulled hemp seeds, citric acid content ranged from 192 to 330 $\mathrm{mg} / 100 \mathrm{~g}$, making it the most abundant organic acid in this seed type. Oxalic acid ranged from 81.7 to $134 \mathrm{mg} / 100 \mathrm{~g}$. Fumaric acid was detected at trace levels in three samples and quantified in the other five. In general, the content was low, with the highest content being 3.489 $\mathrm{mg} / 100 \mathrm{~g}$. To the best of the authors' knowledge, this is the first time the organic acid content of hemp seeds has been reported.

\subsection{Phenolic compounds}

Table 3 presents the identification and quantification of phenolic compounds in the hydromethanolic extracts of hemp seeds, and Table 4 shows the results from whole and dehulled hemp seeds. It was determined that all the hydromethanolic extracts obtained from the eight varieties of whole hemp seeds contained ferulic acid-hexoside, in a range between 0.266 and $0.54 \mathrm{mg} / \mathrm{g}$ extract, corresponding to 'Bialobrzeskie' and 'Tiborszallasi', respectively. Syringic acid was also detected in half of the varieties analysed, with the 'Kompolti' variety containing the highest concentrations of this phenolic acid, $0.72 \mathrm{mg} / \mathrm{g}$ extract. Concerning total phenolic acid concentrations, these values ranged from 0.266 to $1.20 \mathrm{mg} / \mathrm{g}$ extract. The lower value observed in the 'Bialobrzeskie' variety was due to reduced ferulic acid-hexoside concentrations and the lack of syringic acid. On the other hand, the elevated total phenolic acid levels observed in the 'Kompolti' variety was because this variety had the highest syringic acid content and augmented levels of ferulic acid-hexoside, $0.48 \mathrm{mg} / \mathrm{g}$ extract.

All hydromethanolic dehulled hemp seed extracts contained ferulic acid-hexoside and syringic acid. The former ranged from 0.371 to 0.619 $\mathrm{mg} / \mathrm{g}$ extract, and the latter from 0.29 to $0.63 \mathrm{mg} / \mathrm{g}$ extract. The ferulic acid-hexoside range was slightly higher in the hydromethanolic dehulled hemp seed extracts than whole seeds. The maximum syringic acid content was higher in the hydromethanolic whole seed extracts. Total phenolic acids in hydromethanolic dehulled seed extracts ranged from 0.66 to $1.25 \mathrm{mg} / \mathrm{g}$. The maximum values obtained in hydromethanolic extracts of whole and dehulled hemp seeds were similar. However, the minimum value in the dehulled samples was greater due to the presence of syringic acid in the extracts.

A previous study showed that ferulic acid is a minor compound in hemp seeds (Iraki et al., 2019). Additionally, Multari et al. (2016) reported higher levels of the free form of this compound than the bound one in hemp flour. The present results seem consistent with this result since we observed ferulic acid-hexoside. Interestingly, Irakli et al. (2019) did not detect syringic acid in their samples, but Multari et al. (2016) found it in hemp flour. The presence of these phenolic acids is attractive since these compounds have been shown to exhibit antioxidant properties (Cheemanapalli, Mopuri, Ramanjaneyulu, Anuradha, \& Kuman, 2018; Kumar \& Pruthi, 2014).

\subsection{Biological activities}

The results of the antioxidant activity of the hydromethanolic extracts of whole and dehulled hemp seeds are presented in Table 5. The higher antioxidant activities are characterised by lower $\mathrm{EC}_{50}$ values. The lowest $\mathrm{EC}_{50}$ values were detected in the TBARS assay, which required 0.31 to $0.75 \mathrm{mg} / \mathrm{mL}$ of whole seed extract to provide $50 \%$ of the activity. This assay measures the extract's capacity to inhibit the formation of malondialdehyde and other low molecular-weight end-products generated from the ex vivo decomposition of certain lipid peroxidation products (Alonso et al., 2009). We opted to employ porcine brain cells because they are rich in polyunsaturated fatty acids and an established model for lipid peroxidation studies. The $\mathrm{EC}_{50}$ values obtained in the $\beta$-carotene bleaching inhibition capacity assay were slightly higher, ranging from 0.38 to $1.2 \mathrm{mg} / \mathrm{mL}$. The reducing power (EC ${ }_{50} 1.21-2.35$ $\mathrm{mg} / \mathrm{mL}$ ) and the DPPH scavenging activity (EC $502.5-9.2 \mathrm{mg} / \mathrm{mL}$ ) were low.

The hydromethanolic dehulled hemp seed extracts were less active than those obtained from whole seeds. The TBARS and $\beta$-carotene bleaching inhibition capacity assay results exhibited broad $\mathrm{EC}_{50}$ ranges of 0.75 to $2.4 \mathrm{mg} / \mathrm{mL}$ and 0.43 to $2.3 \mathrm{mg} / \mathrm{mL}$, respectively. These seed extracts appeared to lack significant reducing power $\left(\mathrm{EC}_{50} 2.3-5.3 \mathrm{mg} /\right.$ $\mathrm{mL}$ ) and DPPH scavenging activity ( $\left.\mathrm{EC}_{50} 19.1-35.1 \mathrm{mg} / \mathrm{mL}\right)$.

Interestingly, Hong et al. (2015) measured the DPPH scavenging activity of dehulled hemp seeds, and the results were similar to the $\mathrm{EC}_{50}$ values of whole seeds in the present work. However, they carried out 
Table 3

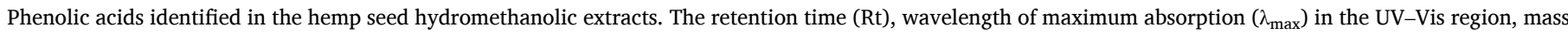
spectral data, and quantification parameters are presented.

\begin{tabular}{|c|c|c|c|c|c|c|c|c|}
\hline Compound & $\begin{array}{l}\mathbf{R t} \\
(\min )\end{array}$ & $\begin{array}{l}\lambda_{\max } \\
(\mathrm{nm})\end{array}$ & $\begin{array}{l}\text { Pseudomolecular ion } \\
{\left[\mathbf{M}-\mathbf{H}^{-}(\mathrm{m} / \mathrm{z})\right.}\end{array}$ & MS $^{2}$ fragments $(m / z)^{*}$ & Standard & Calibration curve & $\begin{array}{l}\text { LOD } \\
(\mu \mathrm{g} / \mathrm{mL})\end{array}$ & $\begin{array}{l}\text { LOQ } \\
(\mu \mathrm{g} / \mathrm{mL})\end{array}$ \\
\hline Unknown & 5.7 & $\begin{array}{l}253 \\
280\end{array}$ & 318 & $\begin{array}{l}301(20), 300(100), 282(5), \\
257(8), 172(6), 128(5)\end{array}$ & - & - & - & - \\
\hline $\begin{array}{l}\text { Ferulic acid- } \\
\text { hexoside }\end{array}$ & 6.5 & 290 & 355 & $193(100)$ & $\begin{array}{l}\text { Ferulic } \\
\text { acid }\end{array}$ & $\begin{array}{l}y=633126 x-185,462 \\
\left(R^{2}=0.9990\right)\end{array}$ & 0.20 & 1.01 \\
\hline Syringic acid & 12.6 & 280 & 197 & 153 (12), $121(100)$ & $\begin{array}{l}\text { Syringic } \\
\text { acid }\end{array}$ & $\begin{array}{l}\mathrm{y}=376056 \mathrm{x}-141,329 \\
\left(\mathrm{R}^{2}=0.9995\right)\end{array}$ & 0.23 & 0.72 \\
\hline
\end{tabular}

LOD: limit of detection; LOQ: limit of quantification.

* The relative abundance of each fragment ion is presented within parentheses.

Table 4

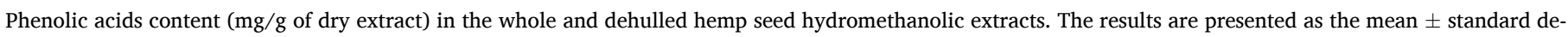
viation $(\mathrm{n}=3)$.

\begin{tabular}{|c|c|c|c|c|c|c|c|c|}
\hline & \multicolumn{8}{|c|}{ Whole hemp seeds } \\
\hline & 'Bialobrzeskie' & 'Carmagnola' & 'Fedora $17^{\prime}$ & 'Felina 32 ' & 'KC Dora' & ‘Kompolti’ & 'Santhica $27^{\prime}$ & 'Tiborszallasi' \\
\hline Ferulic acid-hexoside & $0.266 \pm 0.004^{\mathrm{d}}$ & $0.39 \pm 0.01^{\mathrm{f}}$ & $0.47 \pm 0.02^{\mathrm{b}}$ & $0.33 \pm 0.01^{\mathrm{e}}$ & $0.38 \pm 0.01^{\mathrm{d}}$ & $0.48 \pm 0.02^{\mathrm{b}}$ & $0.43 \pm 0.02^{c}$ & $0.54 \pm 0.02^{\mathrm{a}}$ \\
\hline Syringic acid & nd & nd & nd & $0.431 \pm 0.001^{\mathrm{b}}$ & nd & $0.72 \pm 0.04^{\mathrm{a}}$ & $0.68 \pm 0.05^{\mathrm{a}}$ & $0.35 \pm 0.01^{c}$ \\
\hline \multirow[t]{3}{*}{ TPA } & $0.266 \pm 0.004^{g}$ & $0.39 \pm 0.01^{\mathrm{f}}$ & $0.47 \pm 0.02^{\mathrm{e}}$ & $0.76 \pm 0.02^{\mathrm{d}}$ & $0.38 \pm 0.01^{\mathrm{f}}$ & $1.20 \pm 0.06^{\mathrm{a}}$ & $1.11 \pm 0.06^{\mathrm{b}}$ & $0.89 \pm 0.03^{\mathrm{c}}$ \\
\hline & \multicolumn{8}{|c|}{ Dehulled hemp seeds } \\
\hline & Brand 1 lot 1 & Brand 1 lot 2 & Brand 2 lot 1 & Brand 2 lot 2 & Brand 3 lot 1 & Brand 3 lot 2 & Brand 4 lot 1 & Brand 4 lot 2 \\
\hline Ferulic acid-hexoside & $0.58 \pm 0.03^{b}$ & $0.619 \pm 0.002^{\mathrm{a}}$ & $0.41 \pm 0.03^{\mathrm{d}}$ & $0.41 \pm 0.01^{\mathrm{d}}$ & $0.371 \pm 0.002^{\mathrm{e}}$ & $0.46 \pm 0.01^{c}$ & $0.46 \pm 0.02^{c}$ & $0.39 \pm 0.02^{\mathrm{d}, \mathrm{e}}$ \\
\hline Syringic acid & $0.61 \pm 0.04^{\mathrm{a}}$ & $0.63 \pm 0.01^{\mathrm{a}}$ & $0.30 \pm 0.02^{\mathrm{e}}$ & $0.32 \pm 0.02^{\mathrm{d}, \mathrm{e}}$ & $0.29 \pm 0.01^{\mathrm{e}}$ & $0.35 \pm 0.02^{\mathrm{c}, \mathrm{d}}$ & $0.50 \pm 0.03^{\mathrm{b}}$ & $0.37 \pm 0.03^{c}$ \\
\hline TPA & $1.19 \pm 0.07^{\mathrm{a}}$ & $1.25 \pm 0.02^{\mathrm{a}}$ & $0.71 \pm 0.05^{\mathrm{d}, \mathrm{e}}$ & $0.73 \pm 0.03^{\mathrm{d}, \mathrm{e}}$ & $0.66 \pm 0.01^{\mathrm{e}}$ & $0.81 \pm 0.03^{c}$ & $0.96 \pm 0.04^{\mathrm{b}}$ & $0.77 \pm 0.04^{\mathrm{c}, \mathrm{d}}$ \\
\hline
\end{tabular}

TPA: total phenolic acids; nd: not detected. Different letters in the same line indicate significant differences $(p<0.001)$ between samples.

Table 5

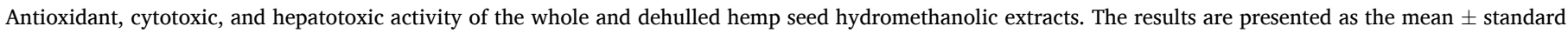
deviation $(\mathrm{n}=3)$.

\begin{tabular}{|c|c|c|c|c|c|c|c|c|c|}
\hline & \multicolumn{8}{|c|}{ Whole hemp seeds } & \multirow[t]{2}{*}{ Positive control } \\
\hline & 'Bialobrzeskie' & ‘Carmagnola’ & 'Fedora $17^{\prime}$ & 'Felina 32 ' & 'KC Dora' & 'Kompolti' & 'Santhica 27 ' & 'Tiborszallasi' & \\
\hline \multicolumn{9}{|c|}{ Antioxidant activity $\left(\mathrm{EC}_{50}, \mathrm{mg} / \mathrm{mL}\right)$} & Trolox \\
\hline DPPH SA & $9.2 \pm 0.3^{\mathrm{a}}$ & $7.6 \pm 0.4^{\mathrm{b}}$ & $3.6 \pm 0.1^{\mathrm{f}}$ & $3.9 \pm 0.1^{\mathrm{e}}$ & $4.7 \pm 0.1^{\mathrm{d}}$ & $2.5 \pm 0.1^{g}$ & $5.9 \pm 0.2^{c}$ & $4.0 \pm 0.2^{\mathrm{e}}$ & $0.042 \pm 0.001$ \\
\hline $\mathrm{RP}$ & $2.05 \pm 0.06^{\mathrm{b}}$ & $1.58 \pm 0.03^{\mathrm{e}}$ & $1.64 \pm 0.04^{\mathrm{d}}$ & $1.21 \pm 0.02^{\mathrm{h}}$ & $1.25 \pm 0.01^{g}$ & $1.31 \pm 0.03^{\mathrm{f}}$ & $2.35 \pm 0.04^{\mathrm{a}}$ & $1.89 \pm 0.05^{\mathrm{c}}$ & $0.041 \pm 0.003$ \\
\hline$\beta$-Carotene BI & $0.86 \pm 0.06^{\mathrm{c}}$ & $1.2 \pm 0.2^{\mathrm{a}, \mathrm{b}}$ & $0.38 \pm 0.01^{\mathrm{e}}$ & $0.7 \pm 0.1^{\mathrm{c}}$ & $1.15 \pm 0.08^{\mathrm{a}}$ & $0.47 \pm 0.05^{\mathrm{d}}$ & $0.49 \pm 0.02^{\mathrm{d}}$ & $1.01 \pm 0.06^{\mathrm{b}}$ & $0.018 \pm 0.001$ \\
\hline TBARS FI & $0.40 \pm 0.04^{\mathrm{d}, \mathrm{e}}$ & $0.38 \pm 0.04^{\mathrm{e}}$ & $0.74 \pm 0.05^{\mathrm{a}}$ & $0.51 \pm 0.01^{\mathrm{b}}$ & $0.31 \pm 0.01^{\mathrm{f}}$ & $0.48 \pm 0.03^{b, c}$ & $0.75 \pm 0.01^{\mathrm{a}}$ & $0.44 \pm 0.01^{\mathrm{c}, \mathrm{d}}$ & $0.023 \pm 0.001$ \\
\hline \multicolumn{9}{|c|}{ Cytotoxic activity $\left(\mathrm{GI}_{50}, \mu \mathrm{g} / \mathrm{mL}\right)$} & Ellipticine \\
\hline HepG2 & $179 \pm 9^{\mathrm{c}}$ & $204 \pm 13^{b}$ & $>400$ & $>400$ & $203 \pm 8^{\mathrm{b}}$ & $334 \pm 11^{\mathrm{a}}$ & $>400$ & $>400$ & $13 \pm 1$ \\
\hline NCI-H460 & $47 \pm 3^{\mathrm{d}}$ & $99 \pm 4^{c}$ & $>400$ & $274 \pm 19^{\mathrm{a}}$ & $121 \pm 6^{\mathrm{b}}$ & $280 \pm 13^{\mathrm{a}}$ & $>400$ & $>400$ & $8.0 \pm 0.2$ \\
\hline HeLa & $72 \pm 4^{d}$ & $292 \pm 6^{b}$ & $>400$ & $>400$ & $227 \pm 11^{\mathrm{c}}$ & $303 \pm 8^{\mathrm{a}}$ & $>400$ & $>400$ & $4.75 \pm 0.05$ \\
\hline MCF-7 & $92 \pm 4^{\mathrm{a}}$ & $215 \pm 13^{b}$ & $>400$ & $>400$ & $216 \pm 11^{b}$ & $302 \pm 15^{\mathrm{a}}$ & $>400$ & $>400$ & $3.7 \pm 0.2$ \\
\hline \multicolumn{9}{|c|}{ Hepatotoxic activity $\left(\mathrm{GI}_{50}, \mu \mathrm{g} / \mathrm{mL}\right)$} & Ellipticine \\
\hline \multirow[t]{3}{*}{ PLP2 } & $271 \pm 19^{\mathrm{b}}$ & $323 \pm 6^{\mathrm{a}}$ & $>400$ & $>400$ & $>400$ & $>400$ & $>400$ & $>400$ & $8.6 \pm 0.1$ \\
\hline & \multicolumn{9}{|c|}{ Dehulled hemp seeds } \\
\hline & Brand 1 lot 1 & Brand 1 lot 2 & Brand 2 lot 1 & Brand 2 lot 2 & Brand 3 lot 1 & Brand 3 lot 2 & Brand 4 lot 1 & Brand 4 lot 2 & \\
\hline \multicolumn{9}{|c|}{ Antioxidant activity $\left(\mathrm{EC}_{50}, \mathrm{mg} / \mathrm{mL}\right)$} & Trolox \\
\hline DPPH SA & $22.1 \pm 0.3^{\mathrm{d}}$ & $19.8 \pm 0.2^{\mathrm{e}}$ & $33.7 \pm 0.3^{\mathrm{b}}$ & $30.1 \pm 0.1^{\mathrm{c}}$ & $35.1 \pm 0.7^{\mathrm{a}}$ & $19.1 \pm 0.5^{\mathrm{f}}$ & $30 \pm 2^{c}$ & $21 \pm 1^{\mathrm{d}, \mathrm{e}}$ & $0.042 \pm 0.001$ \\
\hline $\mathrm{RP}$ & $5.3 \pm 0.2^{\mathrm{a}}$ & $5.2 \pm 0.2^{\mathrm{a}}$ & $2.8 \pm 0.2^{\mathrm{c}}$ & $2.46 \pm 0.08^{\mathrm{d}}$ & $2.3 \pm 0.3^{\mathrm{d}}$ & $3.6 \pm 0.2^{\mathrm{b}}$ & $2.4 \pm 0.2^{\mathrm{d}}$ & $2.4 \pm 0.2^{\mathrm{d}}$ & $0.041 \pm 0.003$ \\
\hline$\beta$-Carotene BI & $1.20 \pm 0.02^{\mathrm{b}}$ & $0.43 \pm 0.06^{\mathrm{e}}$ & $2.128 \pm 0.004^{\mathrm{a}}$ & $1.09 \pm 0.03^{\mathrm{c}}$ & $2.3 \pm 0.2^{\mathrm{a}}$ & $0.75 \pm 0.02^{\mathrm{d}}$ & $1.4 \pm 0.2^{\mathrm{b}, \mathrm{c}}$ & $0.87 \pm 0.09^{d}$ & $0.018 \pm 0.001$ \\
\hline TBARS FI & $2.14 \pm 0.02^{\mathrm{b}}$ & $2.40 \pm 0.04^{\mathrm{a}}$ & $1.0 \pm 0.1^{\mathrm{d}, \mathrm{e}}$ & $1.04 \pm 0.05^{\mathrm{d}}$ & $0.75 \pm 0.06^{\mathrm{f}}$ & $1.25 \pm 0.08^{\mathrm{c}}$ & $0.92 \pm 0.06^{\mathrm{e}}$ & $1.20 \pm 0.03^{\mathrm{c}}$ & $0.023 \pm 0.001$ \\
\hline \multicolumn{9}{|c|}{ Cytotoxic activity $\left(\mathrm{GI}_{50}, \mu \mathrm{g} / \mathrm{mL}\right)$} & Ellipticine \\
\hline HepG2 & $>400$ & $>400$ & $142 \pm 4^{\mathrm{a}}$ & $131 \pm 10^{\mathrm{b}}$ & $114 \pm 8^{c}$ & $>400$ & $>400$ & $>400$ & $13 \pm 1$ \\
\hline NCI-H460 & $>400$ & $>400$ & $77 \pm 6^{\mathrm{d}}$ & $70 \pm 2^{\mathrm{d}}$ & $95 \pm 3^{c}$ & $>400$ & $172 \pm 12^{\mathrm{a}}$ & $160 \pm 13^{b}$ & $8.0 \pm 0.2$ \\
\hline HeLa & $>400$ & $>400$ & $122 \pm 5^{c}$ & $99 \pm 4^{d}$ & $129 \pm 7^{b}$ & $>400$ & $318 \pm 4^{\mathrm{a}}$ & $>400$ & $4.75 \pm 0.05$ \\
\hline MCF-7 & $>400$ & $>400$ & $153 \pm 8^{c}$ & $127 \pm 9^{d}$ & $224 \pm 20^{\mathrm{b}}$ & $>400$ & $>400$ & $251 \pm 23^{\mathrm{a}}$ & $3.7 \pm 0.2$ \\
\hline \multicolumn{9}{|c|}{ Hepatotoxic activity $\left(\mathrm{GI}_{50}, \mu \mathrm{g} / \mathrm{mL}\right)$} & Ellipticine \\
\hline PLP2 & $>400$ & $>400$ & $>400$ & $>400$ & $>400$ & $>400$ & $>400$ & $>400$ & $8.6 \pm 0.1$ \\
\hline
\end{tabular}

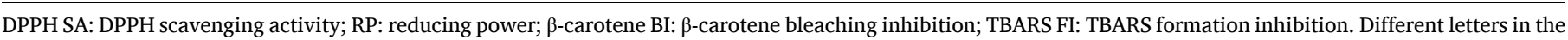
same line indicate significant differences $(p<0.001)$ between samples.

extractions with ethanol and supercritical $\mathrm{CO}_{2}$, which could account for the difference. Chen et al. (2012) analysed the DPPH scavenging activity of dehulled hemp seeds and hemp hulls but not evaluate whole hemp seeds. The authors concluded that the observed activity was due to phenolic compounds. In the present study, it seems that the presence of hull in the seed favoured the antioxidant activity, probably due to the phytochemical constituents it contains, but further work is needed to find possible correlations. 
The cytotoxic activities of the hydromethanolic extracts of whole and dehulled hemp seeds against MCF-7 (breast adenocarcinoma), NCIH460 (non-small cell lung cancer), HeLa (cervical carcinoma), and HepG2 (hepatocellular carcinoma) cell lines and the hepatotoxic activity against PLP2 (liver primary culture) are summarised in Table 5. Lower $\mathrm{GI}_{50}$ values correspond to higher cytotoxic activities in these assays, and $\mathrm{GI}_{50}$ values of more than $400 \mu \mathrm{g} / \mathrm{mL}$ were considered inactive.

Four varieties of the whole hemp seed extracts were active against the four tumour cell lines tested, and another extract was only active against NCI-H460 (Table 5). The 'Bialobrzeskie' variety was found to be the most active, with $\mathrm{GI}_{50}$ values of less than $100 \mu \mathrm{g} / \mathrm{mL}$ against MCF-7, NCI-H460 and HeLa cells, and an GI $_{50}$ of $179 \mu \mathrm{g} / \mathrm{mL}$ against HepG2 cells. The cytotoxic activity was especially marked against NCI-H460 cells because there were five active extracts with low $\mathrm{GI}_{50}$ values. Two varieties, 'Bialobrzeskie' and 'Carmagnola', were active against the PLP2 hepatic line; however, the $\mathrm{GI}_{50}$ values were about $300 \mu \mathrm{g} / \mathrm{mL}$, which does not suggest marked hepatotoxicity.

Not all the hydromethanolic extracts of dehulled hemp seeds displayed cytotoxic activity (Table 5). Three were active against the four tumour cell lines, and two were active against two cell lines. Similar to

Table 6

Antibacterial and antifungal activity of the whole and dehulled hemp seed hydromethanolic extracts.

\begin{tabular}{|c|c|c|c|c|c|c|c|c|c|c|}
\hline & \multicolumn{10}{|c|}{ Whole hemp seeds } \\
\hline & 'Bialobrzeskie' & 'Carmagnola' & 'Fedora $17^{\prime}$ & 'Felina 32 ' & 'KC Dora' & 'Kompolti' & $\begin{array}{l}\text { 'Santhica } \\
27^{\prime}\end{array}$ & 'Tiborszallasi' & PC1 & PC2 \\
\hline \multicolumn{11}{|c|}{ Antibacterial activity (MIC/MBC, mg/mL) } \\
\hline B. cereus & $0.037 / 0.075$ & $0.02 / 0.037$ & $0.075 / 0.15$ & $\begin{array}{l}0.02 / \\
0.037\end{array}$ & $0.01 / 0.02$ & $0.15 / 0.3$ & $0.15 / 0.3$ & $0.01 / 0.018$ & $\begin{array}{l}0.1 / \\
0.2\end{array}$ & $\begin{array}{l}0.25 / \\
0.40\end{array}$ \\
\hline S. aureus & $0.075 / 0.15$ & $0.075 / 0.15$ & $0.3 / 0.6$ & $0.15 / 0.3$ & $\begin{array}{l}0.037 / \\
0.075\end{array}$ & $0.6 / 0.9$ & $0.3 / 0.6$ & $0.15 / 0.3$ & $\begin{array}{l}0.04 / \\
0.1\end{array}$ & $\begin{array}{l}0.25 / \\
0.45\end{array}$ \\
\hline L. monocytogenes & $0.15 / 0.3$ & $0.15 / 0.3$ & $0.9 / 1.2$ & $0.3 / 0.6$ & $0.3 / 0.6$ & $0.6 / 1.2$ & $0.45 / 0.6$ & $0.3 / 0.6$ & $\begin{array}{l}0.2 / \\
0.3\end{array}$ & $0.4 / 0.5$ \\
\hline E. faecalis & $0.075 / 0.15$ & $0.15 / 0.3$ & $0.3 / 0.6$ & $\begin{array}{l}0.075 / \\
0.15\end{array}$ & $0.075 / 0.15$ & $0.2 / 0.6$ & $0.15 / 0.3$ & $0.018 / 0.037$ & $\begin{array}{l}0.2 / \\
0.3\end{array}$ & $\begin{array}{l}0.25 / \\
0.5\end{array}$ \\
\hline E. coli & $0.15 / 0.3$ & $0.15 / 0.3$ & $0.9 / 1.2$ & $0.3 / 0.6$ & $0.3 / 0.6$ & $0.9 / 1.2$ & $0.6 / 0.9$ & $0.3 / 0.6$ & $\begin{array}{l}0.2 / \\
0.3\end{array}$ & $0.4 / 0.5$ \\
\hline S. Typhimurium & $0.2 / 0.3$ & $0.15 / 0.3$ & $0.9 / 1.2$ & $0.3 / 0.6$ & $0.15 / 0.3$ & $0.6 / 0.9$ & $0.6 / 0.9$ & $0.15 / 0.3$ & $\begin{array}{l}0.2 / \\
0.3\end{array}$ & $\begin{array}{l}0.75 / \\
1.2\end{array}$ \\
\hline \multicolumn{11}{|c|}{ Antifungal activity (MIC/MFC, mg/mL) } \\
\hline A. fumigatus & $0.60 / 1.2$ & $1.2 / 1.8$ & $0.60 / 1.2$ & $0.6 / 1.2$ & $0.6 / 1.2$ & $0.3 / 0.6$ & $0.3 / 0.60$ & $0.3 / 0.6$ & $\begin{array}{l}0.25 / \\
0.5\end{array}$ & $\begin{array}{l}0.15 / \\
0.2\end{array}$ \\
\hline A. ochraceus & $0.45 / 0.6$ & $0.6 / 1.2$ & $0.15 / 0.3$ & $0.3 / 0.6$ & $0.15 / 0.3$ & $0.15 / 0.3$ & $0.075 / 0.15$ & $0.15 / 0.3$ & $\begin{array}{l}0.2 / \\
0.5\end{array}$ & $0.1 / 0.2$ \\
\hline A. niger & $0.9 / 1.8$ & $1.2 / 2.4$ & $0.3 / 0.6$ & $0.45 / 1.2$ & $0.3 / 0.6$ & $0.9 / 1.2$ & $0.3 / 0.6$ & $0.6 / 1.2$ & $\begin{array}{l}0.2 / \\
0.5\end{array}$ & $\begin{array}{l}0.15 / \\
0.2\end{array}$ \\
\hline P. ochrochloron & $0.6 / 1.2$ & $0.6 / 1.2$ & $0.15 / 0.3$ & $0.2 / 0.3$ & $0.075 / 0.15$ & $0.45 / 1.2$ & $0.3 / 0.6$ & $0.2 / 0.6$ & $\begin{array}{l}0.2 / \\
0.5\end{array}$ & $\begin{array}{l}0.2 / \\
0.25\end{array}$ \\
\hline P. funiculosum & $0.6 / 1.2$ & $0.6 / 1.2$ & $0.3 / 0.6$ & $0.3 / 0.6$ & $0.075 / 0.15$ & $0.3 / 0.6$ & $0.2 / 0.3$ & $0.2 / 0.6$ & $\begin{array}{l}2.5 / \\
3.5\end{array}$ & $\begin{array}{l}0.2 / \\
0.25\end{array}$ \\
\hline $\begin{array}{l}\text { P. verrucosum var. } \\
\text { cyclopium }\end{array}$ & $0.45 / 0.6$ & $0.9 / 1.8$ & $0.15 / 0.3$ & $0.45 / 1.2$ & $0.15 / 0.3$ & $0.3 / 0.6$ & $0.2 / 0.3$ & $0.45 / 0.6$ & $\begin{array}{l}0.2 / \\
0.3\end{array}$ & $0.1 / 0.2$ \\
\hline & \multicolumn{10}{|c|}{ Dehulled hemp seeds } \\
\hline & Brand 1 lot 1 & Brand 1 lot 2 & $\begin{array}{l}\text { Brand } 2 \\
\text { lot } 1\end{array}$ & $\begin{array}{l}\text { Brand } 2 \\
\text { lot } 2\end{array}$ & $\begin{array}{l}\text { Brand } 3 \\
\text { lot } 1\end{array}$ & $\begin{array}{l}\text { Brand } 3 \text { lot } \\
2\end{array}$ & $\begin{array}{l}\text { Brand } 4 \text { lot } \\
1\end{array}$ & Brand 4 lot 2 & PC1 & PC2 \\
\hline \multicolumn{11}{|c|}{ Antibacterial activity (MIC/MBC, mg/mL) } \\
\hline B. cereus & $0.075 / 0.15$ & $0.1 / 0.15$ & $0.01 / 0.018$ & $\begin{array}{l}0.075 / \\
0.15\end{array}$ & $0.02 / 0.037$ & $0.075 / 0.15$ & $0.075 / 0.15$ & $0.075 / 0.15$ & $\begin{array}{l}0.1 / \\
0.2\end{array}$ & $\begin{array}{l}0.25 / \\
0.4\end{array}$ \\
\hline S. aureus & $0.3 / 0.6$ & $0.3 / 0.6$ & $0.15 / 0.3$ & $0.15 / 0.3$ & $0.05 / 0.15$ & $0.3 / 0.6$ & $0.3 / 0.6$ & $0.15 / 0.3$ & $\begin{array}{l}0.04 / \\
0.1\end{array}$ & $\begin{array}{l}0.25 / \\
0.45\end{array}$ \\
\hline L. monocytogenes & $0.15 / 0.3$ & $0.2 / 0.6$ & $0.1 / 0.3$ & $0.15 / 0.3$ & $0.15 / 0.3$ & $0.2 / 0.3$ & $0.15 / 0.3$ & $0.15 / 0.3$ & $\begin{array}{l}0.2 / \\
0.3\end{array}$ & $0.4 / 0.5$ \\
\hline E. faecalis & $0.15 / 0.3$ & $0.2 / 0.3$ & $\begin{array}{l}0.037 / \\
0.075\end{array}$ & $0.10 / 0.15$ & $0.075 / 0.15$ & $0.1 / 0.15$ & $0.075 / 0.15$ & $0.037 / 0.075$ & $\begin{array}{l}0.2 / \\
0.3\end{array}$ & $\begin{array}{l}0.25 / \\
0.5\end{array}$ \\
\hline E. coli & $0.3 / 0.6$ & $0.3 / 0.6$ & $0.15 / 0.3$ & $0.30 / 0.6$ & $0.075 / 0.15$ & $0.3 / 0.6$ & $0.3 / 0.6$ & $0.2 / 0.3$ & $\begin{array}{l}0.2 / \\
0.3\end{array}$ & $0.4 / 0.5$ \\
\hline S. Typhimurium & $0.3 / 0.6$ & $0.3 / 0.6$ & $0.075 / 0.15$ & $\begin{array}{l}0.075 / \\
0.15\end{array}$ & $0.05 / 0.15$ & $0.2 / 0.3$ & $0.15 / 0.3$ & $0.2 / 0.3$ & $\begin{array}{l}0.2 / \\
0.3\end{array}$ & $\begin{array}{l}0.75 / \\
1.2\end{array}$ \\
\hline \multicolumn{11}{|c|}{ Antifungal activity (MIC/MFC, mg/mL) } \\
\hline A. fumigatus & $0.6 / 1.2$ & $0.6 / 1.2$ & $0.6 / 1.2$ & $0.6 / 1.2$ & 0.601 .2 & $0.3 / 0.6$ & $1.2 / 1.8$ & $1.2 / 2.4$ & $\begin{array}{l}0.25 / \\
0.5\end{array}$ & $\begin{array}{l}0.15 / \\
0.2\end{array}$ \\
\hline A. ochraceus & $0.3 / 0.6$ & $0.2 / 0.6$ & $0.2 / 0.3$ & $0.45 / 0.9$ & $0.3 / 0.9$ & $0.3 / 0.6$ & $0.6 / 1.2$ & $0.6 / 1.2$ & $\begin{array}{l}0.2 / \\
0.5\end{array}$ & $0.1 / 0.2$ \\
\hline A. niger & $0.6 / 1.8$ & $0.45 / 0.9$ & $0.6 / 1.2$ & $1.2 / 1.8$ & $0.45 / 0.9$ & $0.6 / 0.9$ & $1.2 / 2.4$ & $1.2 / 2.4$ & $\begin{array}{l}0.2 / \\
0.5\end{array}$ & $\begin{array}{l}0.15 / \\
0.2\end{array}$ \\
\hline P. ochrochloron & $0.45 / 0.6$ & $0.3 / 0.6$ & $0.6 / 1.2$ & $0.6 / 0.9$ & $0.45 / 0.9$ & $0.6 / 0.9$ & $1.2 / 1.8$ & $1.2 / 1.8$ & $\begin{array}{l}0.2 / \\
0.5\end{array}$ & $\begin{array}{l}0.2 / \\
0.25\end{array}$ \\
\hline P. funiculosum & $0.6 / 1.2$ & $0.6 / 1.2$ & $0.45 / 0.9$ & $0.6 / 1.2$ & $0.45 / 0.9$ & $0.45 / 0.9$ & $0.6 / 1.8$ & $1.2 / 2.4$ & $\begin{array}{l}2.5 / \\
3.5\end{array}$ & $\begin{array}{l}0.2 / \\
0.25\end{array}$ \\
\hline $\begin{array}{l}\text { P. verrucosum var. } \\
\text { cyclopium }\end{array}$ & $0.6 / 1.2$ & $0.6 / 1.2$ & $0.6 / 1.2$ & $0.6 / 1.2$ & $0.6 / 1.2$ & $0.6 / 1.2$ & $1.2 / 1.8$ & $1.2 / 2.4$ & $\begin{array}{l}0.2 / \\
0.3\end{array}$ & $0.1 / 0.2$ \\
\hline
\end{tabular}

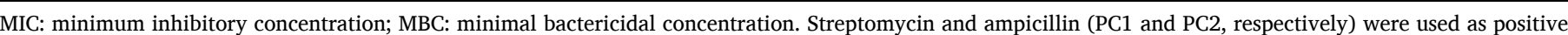

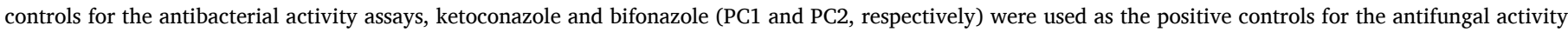
assays. 
whole hemp seeds, the extracts displayed significant cytotoxic activity against NCI-H460. This result is the line with more active extracts against it, and the $\mathrm{GI}_{50}$ values were lower than against the other tumour cell lines. None of the hydromethanolic dehulled hemp seed extracts displayed hepatotoxic activity, as evidenced by $\mathrm{GI}_{50}$ values of greater than $400 \mu \mathrm{g} / \mathrm{mL}$.

Chen et al. (2013) identified cannabisin B as a compound with activity against HepG2. We did not detect this compound in the analysed samples. However, some hemp seed extracts displayed activity against this cell line, indicating that the extracts contain other active phytochemicals. Logarušic et al. (2019) demonstrated the activity of hemp protein hydrolysates against HeLa, but some of the crude extracts were also active against it. Moccia et al. (2019) studied the cytotoxic activity of hemp seed extracts against different human colorectal cell lines, Caco2 and HT-29, and showed that they did not interfere with growth.

A summary of the antimicrobial and antifungal activity results with hydromethanolic whole and dehulled hemp seed extracts against the bacteria and fungi tested are presented in Table 6. Marked antibacterial activity against $B$. cereus was confirmed since almost all the hydromethanolic whole hemp seed extracts had lower MIC and MBC values than the positive controls (MIC $0.1 \mathrm{mg} / \mathrm{mL}$ and MBC $0.2 \mathrm{mg} / \mathrm{mL}$ ). Two of the extracts were more active than ampicillin (MIC $0.25 \mathrm{mg} / \mathrm{mL}$ and MBC $0.40 \mathrm{mg} / \mathrm{mL}$ ). It is worth mentioning that the activity against E. faecalis also stood out. However, in this case, six extracts were more active than the two positive controls (MIC $0.2 \mathrm{mg} / \mathrm{mL}$ and MBC $0.3 \mathrm{mg}$ / $\mathrm{mL}$ ), and 'Kompolti' variety had a MIC value lower than ampicillin (MIC $0.25 \mathrm{mg} / \mathrm{mL}$ and $\mathrm{MBC} 0.5 \mathrm{mg} / \mathrm{mL}$ ) and was equivalent to streptomycin. The most active extracts were from the 'Bialobrzeskie' and 'Carmagnola' varieties, with MIC and MBC values lower than the two positive controls, except against $S$. aureus, for which the MIC and MBC values were only lower than ampicillin (MIC $0.25 \mathrm{mg} / \mathrm{mL}$ and $\mathrm{MBC} 0.45 \mathrm{mg} / \mathrm{mL}$ ). Notably, the hydromethanolic extract of the 'KC Dora' variety displayed substantial antibacterial activity against B. cereus, S. aureus, E. faecalis, and $S$. Typhimurium, with MIC and MBC values lower than the positive controls.

The antifungal activity of hydromethanolic extracts of whole hemp seeds against the Aspergillus tested was not remarkable. However, the extract obtained from 'Santhica 27' produced MIC and MFC values lower than the two positive controls (MIC 0.15 and MFC $0.02 \mathrm{mg} / \mathrm{mL}$ ). The antifungal activity against the Penicillium tested was similar, mainly against $P$. funiculosum. The most active extract was from the 'KC Dora' variety, which had MIC and MFC values against $P$. ochrochloron and $P$. funiculosum lower than the two positive controls (MIC $0.2 \mathrm{mg} / \mathrm{mL}$ and MFC $0.25 \mathrm{mg} / \mathrm{mL}$ ). Additionally, the MIC and MFC values of the ' $\mathrm{KC}$ Dora' variety extract against $P$. verrucosum var. cyclopium were lower than those of ketoconazole (MIC $0.2 \mathrm{mg} / \mathrm{mL}$ and MFC $0.3 \mathrm{mg} / \mathrm{mL}$ ).

The antibacterial activity of hydromethanolic extracts of dehulled hemp seeds was better than that of whole seeds, which may suggest the involvement of lipophilic constituents (either as bioactives or facilitators of the interaction of antibacterial compounds with the cell membrane). All extracts showed lower MIC and MBC values than the two positive controls against B. cereus, E. faecalis, and L. monocytogenes, except for one of the extracts that had a higher MBC value. In addition, six of these extracts were more active than the two positive controls against $S$. Typhimurium and three against $E$. coli. On the contrary, the antifungal activity of the hydromethanolic extracts of dehulled hemp seeds was less effective than whole hemp seeds. None of the extracts had MIC and MFC values lower than those of the two positive controls.

Frassinetti, Gabriele, Moccia, Longo, and Di Giogia (2020) tested the antimicrobial activity of ethanolic extracts of hemp seeds. Their results against $S$. aureus, E. faecalis, E. coli and $S$. Typhimurium were slightly higher than in this study, but the strains differed. They also tested the extracts against Enterobacter aerogenes, but the activity was not remarkable. Sokmen, Jones, and Erturk (1999) reported that the methanolic extracts of hemp seeds did not inhibit the growth of B. cereus, $S$. aureus, E. coli or the yeast Candida albicans. However, we found that hydromethanolic extracts were active against these bacteria, especially B. cereus.

\section{Conclusions}

A comprehensive composition study on whole and dehulled hemp seeds is presented. Both contain interesting amounts of fat and protein, but whole seeds exhibit higher fibre content than dehulled seeds. Despite the attenuated fibre content of dehulled seeds, they could use the nutrition claim "source of fibre", while whole seeds could use the "high fibre" claim. Additionally, both could use the "source of protein" claim. The primary organic acids detected in the hemp seeds were citric acid and oxalic acid. Moreover, ferulic acid-hexoside and syringic acid were the most abundant phenolic acids detected in the hydromethanolic hemp seed extracts. Interestingly, the antioxidant activity of the hydromethanolic extracts of whole seeds was better than that of dehulled seeds. This activity was particularly evident in the $\beta$-carotene bleaching inhibition and especially the TBARS assays. We observed that some extracts displayed notable cytotoxic activity against NCI-H460 and that dehulled seed extracts exhibited antibacterial activity against $B$. cereus, L. monocytogenes, and E. faecalis. In general, the antibacterial activity of the hydromethanolic seed extracts was better than the antifungal activity. However, future studies are needed to establish possible correlations between compounds and bioactivities. Finally, the nutritional composition and potential bioactivities make hemp seeds a potentially highly beneficial food.

\section{Declaration of Competing Interest}

The authors declare that they have no known competing financial interests or personal relationships that could have appeared to influence the work reported in this paper.

\section{Acknowledgements}

The authors are grateful to ALIMNOVA Research Group 95105 (Fundación Sabor y Salud-UCM, ref. 317/2020), as well as to the Foundation for Science and Technology (FCT, Portugal) for financial support through national funds FCT/MCTES to CIMO (UIDB/00690/ 2020). J.I. Alonso-Esteban thanks his grant (2016/01 M) to the Rafael Folch Foundation. R.C. Calhelha and L. Barros thank the national funding by FCT, P.I., through the institutional scientific employment program-contract, and J. Pinela (CEECIND/01011/2018) through the individual scientific employment program-contract. To FEDER-Interreg España-Portugal programme for financial support through the project TRANSCOLAB 0612_TRANS_CO_LAB_2_P. Also to the Ministry of Education, Science and Technological Development of Republic of Serbia (451-03-9/2021-14/200007).

\section{References}

Alonso, C., Barba, C., Rubio, L., Scott, S., Kilimnik, A., Coderch, L., .. Parra, J. L. (2009). An ex vivo methodology to assess the lipid peroxidation in stratum corneum. Journal of Photochemistry and Photobiology B: Biology, 97(2), 71-76. https://doi.org/ 10.1016/j.jphotobiol.2009.08.003

Alonso-Esteban, J. I., González-Fernández, M. J., Fabrikov, D., Torija-Isasa, E., SánchezMata, M. C., \& Guil-Guerrero, J. L. (2020). Hemp (Cannabis sativa L.) varieties: fatty acid profiles and upgrading of $\gamma$-linolenic acid-containing hemp seed oils. European Journal of Lipid Science and Technology, 122, Article 1900445. 10.1002/ ejlt.201900445.

Aluko, R. E. (2017). Hemp Seed (Cannabis sativa L.) Proteins: Composition, Structure, Enzymatic Modification, and Functional or Bioactive Properties. In S. R. Nadathur, J. P. D. Wanasundara, \& L. Scanlin (Eds.), Sustainable Protein Sources (pp. 121-132). Academic Press.

Bessada, S. M. F., Barreira, J. C. M., Barros, L., Ferreira, I. C. R. F., \& Oliveira, M. B. P. P. (2016). Phenolic profile and antioxidant activity of Coleostephus myconis (L.) Rchb.f.: An underexploited and highly disseminated species. Industrial Crops and Products, 89, 45-51. https://doi.org/10.1016/j.indcrop.2016.04.065

Callaway, J. C. (2004). Hempseed as a nutritional resource: An overview. Euphytica, 140 (1-2), 65-72. https://doi.org/10.1007/s10681-004-4811-6 
Callaway, J. C., \& Pate, D. W. (2009). Hempseed oil. In R. A. Moreau, \& A. Kamal-Eldin (Eds.), Gourmet and Health-Promoting Specialty Oils (pp. 185-213). American Oil Chemists Society Press.

Cheemanapalli, S., Mopuri, R., Ramanjaneyulu, G., Anuradha, C. M., \& Kuman, C. S. (2018). Syringic acid (SA) - A review of its occurrence, biosynthesis, pharmacological and industrial importance. Biomedicine \& Pharmacotherapy, 108, 547-557. https://doi.org/10.1016/j.biopha.2018.09.069

Chen, T., Hao, J., He, J., Zhang, J., Li, Y., Liu, R., \& Li, L. (2013). Cannabisin B induces autophagic cell death by inhibiting the AKT/mTOR pathway and S phase cell cycle arrest in HepG2 cells. Food Chemistry, 138(2-3), 1034-1041. https://doi.org/ 10.1016/j.foodchem.2012.11.102

Chen, T., He, J., Zhang, J., Li, X., Zhang, H., Hao, J., \& Li, L. (2012). The isolation and identification of two compounds with predominant radical scavenging activity in hempseed (seed of Cannabis sativa L.). Food Chemistry, 134(2), 1030-1037. https:// doi.org/10.1016/j.foodchem.2012.03.009

European Commission. (2021). Plant variety database. Agricultural plant species. Retrieved from http://ec.europa.eu/food/plant/plant_propagation_material/plant_variet y_catalogues_databases/search/public/index.cfm? event=SearchForm\&ctl_type=A. Accessed April 1, 2021.

European Parliament \& Council of the European Union. (2006). Regulation (EC) No 1924/2006 of the European Parliament and of the Council of 20 December 2006 on nutrition and health claims made on foods. Official Journal of the European Union, $L$ 404, 9-25.

European Parliament \& Council of the European Union. (2011). Regulation (EU) No $1169 / 2011$ of the European Parliament and of the Council of 25 October 2011 on the provision of food information to consumers, amending Regulations (EC) No 1924/ 2006 and (EC) No 1925/2006 of the European Parliament and of the Council, and repealing Commission Directive 87/250/EEC, Council Directive 90/496/EEC, Commission Directive 1999/10/EC, Directive 2000/13/EC of the European Parliament and of the Council, Commission Directives 2002/67/EC and 2008/5/EC and Commission Regulation (EC) No 608/2004. Official Journal of the European Union, L 304, 18-63.

European Parliament \& Council of the European Union. (2013). Regulation (EU) No 1307/2013 of the European Parliament and of the Council of 17 December 2013 establishing rules for direct payments to farmers under support schemes within the framework of the common agricultural policy and repealing Council Regulation (EC) No 637/2008 and Council Regulation (EC) No 73/2009. Official Journal of the European Union, L 347, 608-670.

Flores-Sánchez, I. J., \& Verpoorte, R. (2008). Secondary metabolism in cannabis. Phytochemical Reviews, 7, 615-639. https://doi.org/10.1007/s11101-008-9094-4

Frassinetti, S., Gabriele, M., Moccia, E., Longo, V., \& Di Giogia, D. (2020). Antimicrobial and antibiofilm activity of Cannabis sativa L. seeds extract against Staphylococcus aureus and growth effects on probiotic Lactobacillus spp. LWT-Food. Science and Technology, 124, Article 109149. https://doi.org/10.1016/j.lwt.2020.109149

Horwitz, W. (2000). Official methods of analysis of AOAC International ((17th ed.).). AOAC International.

Hong, S., Sowndhararajan, K., Joo, T., Lim, C., Cho, H., Kim, S., ... Joo., W.. (2015). Ethanol and supercritical fluid extracts of hemp seed (Cannabis sativa L.) increase gene expression of antioxidant enzymes in HepG2 cells. Asian Pacific Journal of Reproduction, 4, 147-152. https://doi.org/10.1016/S2305-0500(15)30012-9

House, J. D., Neufeld, J., \& Leson, G. (2010). Evaluating the quality of protein from hemp seed (Cannabis sativa L.) products through the use of the protein digestibilitycorrected amino acid score method. Journal of Agricultural and Food Chemistry, 58, 11801-11807. https://doi.org/10.1021/jf102636b

Irakli, M., Tsaliki, E., Kalivas, A., Kleisiaris, F., Sarrou, E., \& Cook, C. M. (2019). Effect of genotype and growing year on the nutritional, phytochemical, and antioxidant properties of industrial hemp (Cannabis sativa L.) seeds. Antioxidants, 8, Article 491. 10.3390/antiox8100491.

Kumar, N., \& Pruthi, V. (2014). Potential applications of ferulic acid from natural sources. Biotechnology Reports, 4, 86-93. https://doi.org/10.1016/j. btre.2014.09.002

Logarušić, M., Slivac, I., Radošević, K., Bagović, M., Redovniković, I. R., \& Srček, V. G. (2019). Hempseed protein hydrolysates' effects on the proliferation and induced oxidative stress in normal and cancer cell lines. Molecular Biology Reports, 46, 6079-6085. https://doi.org/10.1007/s11033-019-05043-8
Moccia, S., Siano, F., Russo, G. L., Volpe, M. G., La Cara, F., \& Pacifico, S. (2019). Antiproliferative and antioxidant effect of polar hemp extracts (Cannabis sativa L., Fedora cv.) in human colorectal cell lines. International Journal of Food Science and Nutrition, 71, 410-423. https://doi.org/10.1080/09637486.2019.1666804

Multari, S., Neacsu, M., Scobbie, L., Cantlay, L., Duncan, G., Vaughan, N., . . Russell, W. R. (2016). Nutritional and phytochemical content of high-protein crops. Journal of Agricultural and Food Chemistry, 64, 7800-7811. https://doi.org/10.1021/ acs.jafc.6b00926

Osborne, D. R., \& Voogt, L. (1986). Análisis de los nutrientes de los alimentos. Acribia.

Pereira, C., Barros, L., Carvalho, A. M., \& Ferreira, I. C. F. R. (2011). Nutritional composition and bioactive properties of commonly consumed wild greens: Potential sources for new trends in modern diets. Food Research International, 44, 2634-2640. https://doi.org/10.1016/j.foodres.2011.05.012

Pereira, C., Barros, L., Carvalho, A. M., \& Ferreira, I. C. F. R. (2013). Use of UFLC-PDA for the analysis of organic acids in thirty-five species of food and medicinal plants. Food Analytical Methods, 6, 1337-1344. https://doi.org/10.1007/s12161-012-9548-6

Pinela, J., Barreira, J. C. M., Barros, L., Cabo Verde, S., Antonio, A. L., Carvalho, A. M., ... Ferreira, I. C. F. R. (2016). Suitability of gamma irradiation for preserving fresh-cut watercress quality during cold storage. Food Chemistry, 206, 50-58. https://doi.org/ 10.1016/j.foodchem.2016.03.050

Pinela, J., Barros, L., Dueñas, M., Carvalho, A. M., Santos-Buelga, C., \& Ferreira, I. C. F. R. (2012). Antioxidant activity, ascorbic acid, phenolic compounds and sugars of wild and comercial Tuberaria lignosa samples: Effects of drying and oral preparation methods. Food Chemistry, 135, 1028-1035. https://doi.org/10.1016/j. foodchem.2012.05.038

Pires, T. C. S. P., Dias, M. I., Barros, L., Calhelha, R. C., Alves, M. J., Oliveira, M. B. P. P., .. Ferreira, I. C. R. F. (2018). Edible flowers as sources of phenolic compounds with bioactive potential. Food Research International, 105, 580-588. https://doi.org/ 10.1016/j.foodres.2017.11.014

Schultz, C. J., Lim, W. L., Khor, S. F., Neumann, K. A., Schultz, J. M., Ansari, O., .. Burton, M. A. (2020). Consumer and health-related traits of seed from selected commercial and breeding lines of industrial hemp, Cannabis sativa L. Journal of Agriculture and Food Research, 2, Article 100025. https://doi.org/10.1016/j. jafr.2020.100025

Small, E. (2015). Evolution and classification of Cannabis sativa (Marijuana, Hemp) in relation to Human Utilization. The Botanical Review, 81, 189-294. https://doi.org/ 10.1007/s12229-015-9157-3

Small, E., \& Naraine, S. G. U. (2016). Size matters: Evolution of large drug-secreting resin glands in elite pharmaceutical strains of Cannabis sativa (marijuana). Genetic Resources and Crop Evolution, 63, 349-359. https://doi.org/10.1007/s10722-0150254-2

Soković, M., \& van Griensven, L. J. L. D. (2006). Antimicrobial activity of essential oils and their components against the three major pathogens of the cultivated button mushroom, Agaricus bisporus. European Journal of Plant Pathology, 116, 211-224. https://doi.org/10.1007/s10658-006-9053-0

Sokmen, A., Jones, B. M., \& Erturk, M. (1999). The in vitro antibacterial activity of Turkish medicinal plants. Journal of Ethnopharmacology, 67, 79-86. https://doi.org/ 10.1016/S0378-8741(98)00189-5

Soković, M., Glamočlija, J., Marin, P. D., Brkić, D., \& van Griensven, L. J. L. D. (2010). Antibacterial effects of the essential oils of commonly consumed medicinal herbs using an in vitro model. Molecules, 15, 7532-7546. https://doi.org/10.3390/ molecules15117532

USDA. (2019). FoodData Central. Retrieved from https://fdc.nal.usda.gov/fdc-app. html\#/food-details/170148/nutrients. Accessed April 12, 2021.

Van Soest, P. J., \& Wine, R. H. (1967). Use of detergents in analysis of fibrous feeds. IV. Determination of plant cell-wall constituents. Journal of Association of Official Analytical Chemists, 50, 5-55. https://doi.org/10.1093/jaoac/50.1.50

Vonapartis, E., Aubin, M. P., Seguin, P., Mustafa, A. F., \& Charron, J. B. (2015). Seed composition of ten industrial hemp cultivars approved for production in Canada. Journal of Food Composition and Analysis, 39, 8-12. https://doi.org/10.1016/j. jfca.2014.11.004

Zając, M., Guzik, P., Kulawik, P., Tkaczewska, J., Florkiewitcz, A., \& Migdał, W. (2019). The quality of pork loaves with the addition of hemp seeds, de-hulled hemp seeds, hemp protein and hemp flour. LWT-Food Science and Technology, 105, 190-199. https://doi.org/10.1016/j.lwt.2019.02.013 